\title{
Fate of Particulate Matter from Cruise-Ship Emissions in Glacier Bay during the 2008 Tourist Season
}

\author{
Michael Pirhalla ${ }^{1}$, Scott Gende ${ }^{2}$, Nicole Mölders ${ }^{1 *}$ \\ ${ }^{1}$ Department of Atmospheric Sciences, Geophysical Institute and College of Natural Science and Mathematics, \\ University of Alaska Fairbanks, Fairbanks, AK, USA \\ ${ }^{2}$ National Park Service, Glacier Bay Field Station, Juneau, AK, USA \\ Email: cmoelders@alaska.edu
}

Received 10 July 2014; revised 6 August 2014; accepted 1 September 2014

Copyright (C) 2014 by authors and Scientific Research Publishing Inc.

This work is licensed under the Creative Commons Attribution International License (CC BY). http://creativecommons.org/licenses/by/4.0/

(c) (i) Open Access

\begin{abstract}
Simulations from the Weather Research and Forecasting Model, inline coupled with chemistry, were used to examine the fate of particulate matter with diameter of $10 \mu \mathrm{m}$ or less $\left(\mathrm{PM}_{10}\right)$ in Glacier Bay, Alaska during the $\mathbf{2 0 0 8}$ tourist season. The simulations demonstrated that mesoscale and synoptic scale weather systems affect the residence time of $\mathbf{P M}_{10}$, the magnitude of concentrations, and its transport in and out of Glacier Bay. Strong inversions exceeding $\left.2 \mathrm{~K}_{(100 \mathrm{~m}}\right)^{-1}$ cause notable trapping of pollutants from cruise-ship emissions, increasing $\mathrm{PM}_{10}$ concentrations up to $43 \%$ compared to days with cruise-ship visits without the presence of an inversion. Inversions occurred locally in Glacier Bay on $42 \%$ of the 124-day tourist season with an average lifetime of $9 \mathrm{~h}$. Pollutants occasionally originated from outside the National Park when southerly winds advected pollutants from ship traffic in Icy Strait. Occasionally, orographically forced lifting over the Fairweather Mountains transported pollutants from the Gulf of Alaska into Glacier Bay. While hourly (daily) $\mathrm{PM}_{10}$ concentrations reached $\sim 44 \mu \mathrm{g} \cdot \mathrm{m}^{-3}\left(22 \mu \mathrm{g} \cdot \mathrm{m}^{-3}\right)$ in some areas of Glacier Bay, overall seasonal average $\mathrm{PM}_{10}$ concentrations were below $2 \mu \mathrm{g} \cdot \mathrm{m}^{-3}$. Despite up to two cruise-ship visits per day, Glacier Bay still has pristine air quality. Surface and upper air meteorological state variables were evaluated through an extensive network of surface and radiosonde observations, which demonstrated that the model was able to capture the meteorological conditions well.
\end{abstract}

\section{Keywords}

Cruise-Ship Emissions, Temperature Inversions, Particulate Matter, Glacier Bay National Park, Pristine Air, WRF/Chem

\footnotetext{
${ }^{*}$ Corresponding author.

How to cite this paper: Pirhalla, M., Gende, S. and Mölders, N. (2014) Fate of Particulate Matter from Cruise-Ship Emissions in Glacier Bay during the 2008 Tourist Season. Journal of Environmental Protection, 5, 1235-1254. 


\section{Introduction}

Glacier Bay National Park and Preserve, Alaska (hereafter called Glacier Bay), is one of the most pristine glacial fjord areas in the world, comprising a notable part of the 24.3 million-acre Kluane/Wrangell-St. Elias/Glacier Bay/Tatshenshini-Alsek World Heritage Site, and one of the largest marine protected areas in the northern hemisphere. The park includes more than 2.6 million acres of federally designated candidate "wilderness" areas constituting one of the largest, and one of the few marine-based units in the U.S. National Wilderness Preservation System. The pristine nature and wilderness areas of the park were part of its founding mandate: the park was established to protect the glacial landscape and associated natural processes for science and discovery in a wilderness setting [1].

While Glacier Bay is characterized by large areas of marine and terrestrial wilderness, a mandate of all U.S. national parks is to provide opportunities for visitation and enjoyment. There are no roads connecting Glacier Bay to outside areas of Alaska, meaning that the park is accessed almost exclusively by marine vessels, including commercial cruise-ships. Cruise-ships are by far the largest (mean length is $270 \mathrm{~m}$ ) and primary means by which people visit Glacier Bay. Currently, 225 cruise-ship entries are permitted during the 5-month tourist season (May 15-September 15), constituting over 400,000 ( 97\% of total) visitors annually.

While cruise-ships are central for allowing visitor access to Glacier Bay, a recurring management issue is to understand the extent or severity by which ships may impact park resources, including air quality and visibility. Cruise-ships are the primary source of anthropogenic emissions, releasing pollutants directly into the relatively clean marine boundary layer in Glacier Bay [2]. Cruise-ships emit soot containing ultrafine particles and primary pollutants like sulfur dioxide, ammonia, nitrogen oxides, just to mention a few. The primary pollutants react with naturally available atmospheric compounds, such as volatile organic compounds, thereby producing particulate matter (PM). PM can swell from uptake of water vapor in the air, leading to haze and degraded visibility [2] (Figure 1).

The impacts of cruise-ship emissions on local air quality depend in large part on the surface and atmospheric conditions, including the presence of temperature inversions. Topographically, the park is characterized by extensive ice fields and mountainous habitat which provides favorable conditions for temperature inversions to form during summer months [3], particularly due to radiative cooling and cold air drainage. Although
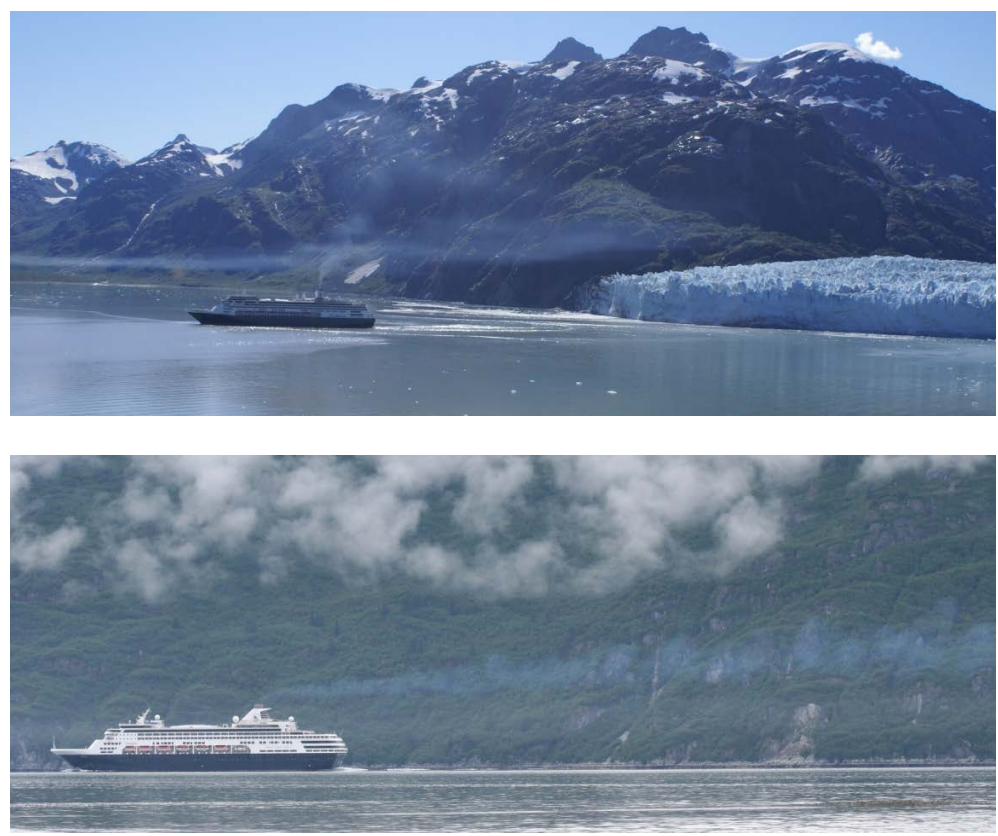

Figure 1. Photos of emission plumes from cruise-ships in Glacier Bay. Due to low level inversions and weak winds, exhaust smoke does not readily escape or diffuse. It remains stationary just at the inversion level. The particles begin to swell since the air has high values of relative humidity. The haze particles become visible, reducing the overall visibility. 
solar insolation may persist for many hours at $59^{\circ} \mathrm{N}$ latitude, the sun is relatively low in the sky. Thus, tall mountains, including those in the Fairweather Range (>4500 m) may shorten the time of direct insolation. The stable conditions associated with inversions can trap pollutants [4] and provide a suitable environment for haze formation [2]. With the absence of moderate winds or storm systems to sweep out stagnant air, inversions may persist for hours to days until the air is recirculated [5] [6]. Together, these conditions result in accumulation of locally emitted pollutants, rather than long-range transport of pollutants, driving the cleanliness of the air below the inversion [7].

Historically, concerns related to cruise-ship emissions have been identified, although few studies have been enacted. In 1976/77, temperature inversions were found to exist on approximately one-third of all days from June 13 to July 21. The inversions lasted for at least a part of the day, and were most common in the early morning (0300 - 0830 LT) under clear sky conditions when the radiation balance was negative [3]. While the topographic and atmospheric conditions are not likely to have changed appreciably since the 1970s, the average size, number, and technology of cruise-ships entering the park have changed substantially over the past several decades [8]. Thus, a primary information gap has been to quantify the frequency and severity of inversions in the park relative to current ship conditions.

Given the absence of in-situ meteorological and air-quality observations in and around Glacier Bay, we turn to air-quality modeling as a tool to understand the fates of airborne particles stemming from cruise-ship emissions in Glacier Bay. For this study we build on recent results of an activity based emissions inventory of cruiseships [2] and refine the Weather Research and Forecasting Model (WRF) [9], coupled with a chemistry package (WRF/Chem) [10] [11] to address the nature of inversions in Glacier Bay relative to cruise-ship emissions. Our goal was to understand the fate and potential impact from airborne particles originating from cruise-ships in Glacier Bay to help park management better weigh the trade-offs of air-quality impacts from ships, with the benefits of meeting the visitation mandate.

\section{Experimental Design and Methodology}

\subsection{Model Description}

WRF/Chem was used to examine the fate of particulate matter in Glacier Bay for the 2008 tourist season. We applied WRF/Chem in the setup described by Mölders et al. [2], which was as follows: Cloud microphysical processes were considered by the WRF Single-Moment 5-class scheme [12]. Subgrid-scale convective clouds were accounted for by the Grell and Dévényi cumulus-ensemble scheme [13]. The two-stream, 11-spectral band Goddard scheme, under consideration of radiative feedback with clouds, aerosols, and chemistry [14], was used for shortwave radiation [15]. The Rapid Radiative Transfer Model [16] was applied for longwave radiation. Processes in the atmospheric boundary layer (ABL) followed the eta surface layer Mellor-Yamada-Janjić scheme [17] [18]. A modified version of the NOAH Land Surface Model [19] served to determine heat and moisture fluxes over land and water surfaces, and to account for subgrid-scale fluxes associated with snow, soil moisture, frozen ground, and vegetation.

Atmospheric oxidants, air pollutants, and inorganic chemistry were determined using the Regional Acid Deposition Model version 2 for gas-phase chemistry mechanisms [20]. Volatile organic compounds were represented with 26 stable species and 16 short-lived intermediate peroxy radicals, following Middleton et al. [21]. Photolysis frequencies were calculated for 21 photochemical reactions [22]. Primary and secondary organic aerosol processes were determined through the Modal Aerosol Dynamics Model for Europe [23], and the Secondary Organic Aerosol Model [24]. Dry deposition of trace gases was calculated by a surface resistance parameterization [25] with modifications for specific Alaska surfaces [26].

Biogenic emissions were calculated for isoprenes, monoterpenes, and biogenic volatile organic compounds from vegetation and nitrogen emissions from the soil [27] [28]. The emissions from ships were determined through an activity-based inventory [2].

\subsection{Simulations}

The model domain was centered over Glacier Bay and encompassed the entire Alaska Panhandle, as well as portions of British Columbia and Yukon Territory (Figure 2). It contained $110 \times 110$ grid cells with a $7 \mathrm{~km}$ grid increment, and 28 vertical layers from the surface to $100 \mathrm{hPa}$. 

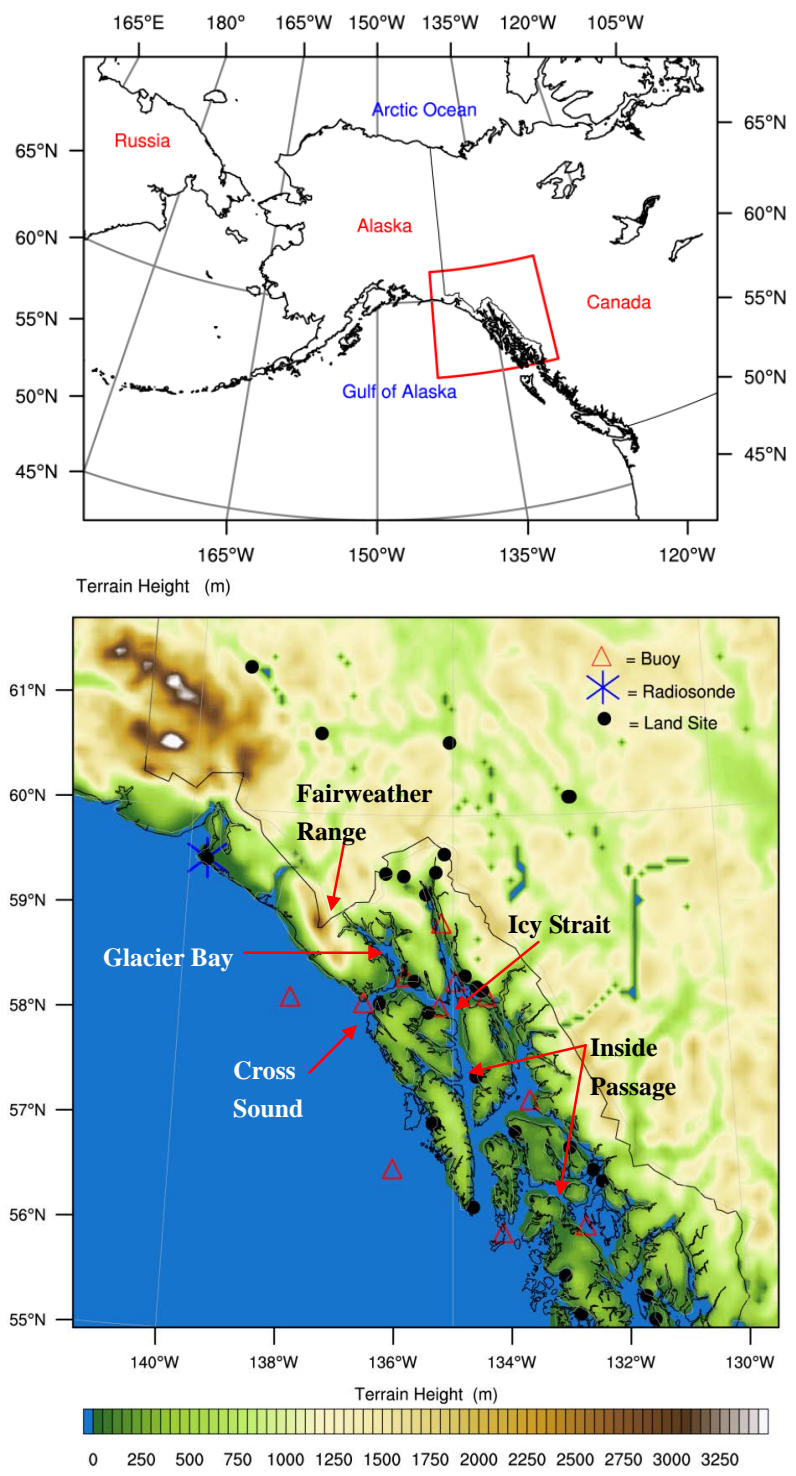

\begin{abstract}
Figure 2. The top panel displays the State of Alaska and surrounding geography. The domain of interest is indicated with a red polygon. The bottom panel shows a zoomed-in map of the model domain, shaded by terrain height and overlaid with locations of surface meteorological sites. Buoys are denoted with red triangles, land-based sites (NCDC and RWIS) with black circles, and the radiosonde site with a blue asterisk. Note that the locations of sites are skewed to settlements and easily accessible regions, and the radiosonde site is co-located with a surface site.
\end{abstract}

Initial and boundary conditions for meteorological, soil, and snow data were obtained from the National Centers for Environmental Prediction 6-hour global final analysis data at $1^{\circ} \times 1^{\circ}$ resolution. Idealized mean Alaska background chemical profiles served to initialize the chemical fields, and to provide lateral boundary conditions during the simulation.

Simulations ran from May 15 to September 15, 2008, which covered the highest cruise-ship activity during the tourist season, as well as the peak-temperature period for Southeast Alaska. Meteorology was initialized every five days, but the chemical distributions at the end of each day served as initial conditions for the simulation of the following day.

Note that cruise-ships almost exclusively represent the source of emissions in Glacier Bay. Of the other ma- 
rine vessels that access the park, most are small $(<12 \mathrm{~m})$ and many are powered by 4 -stroke outboard gas engines. A single tour vessel makes a daily trip from the mouth of the park and up its west arm; minimal sources of other anthropogenic emissions are present anywhere in the park, especially outside of Bartlett Cove, which is near the mouth of Glacier Bay where National Park Service (NPS) headquarters are located.

\subsection{Evaluation and Analysis}

The simulations were evaluated by means of observations (temperature, dew-point temperature, atmospheric pressure, relative humidity, wind speed, and wind direction) from 42 meteorological sites. Eleven sites were buoys. We also evaluated twice daily radiosonde launches from the Yakutat Airport, available at 1500 and 0300 LT. No chemical observations were available. The performance skill was quantified by the correlation coefficient (r), mean bias, standard deviation error (SDE), root mean square error (RMSE), and variance.

To assess the fate of $\mathrm{PM}_{10}$ in Glacier Bay, simulated inversion frequencies, strengths, thicknesses, durations, and locations inside of Glacier Bay were determined using the method developed by Pirhalla [29]. Herein, an inversion was identified by air-temperature profiles rather than temperature profiles as this is sufficient for the purpose of this study. Note that the obtained inversion height is the same for temperature and potential temperature profiles. An inversion was identified in a grid column when the change in temperature with change in height (dT/dz) was positive and greater than or equal to $0.5 \mathrm{~K}(100 \mathrm{~m})^{-1}$. The algorithm checked for more than one inversion per grid column and per time. Furthermore, the fate of pollutants was examined for the various inversion conditions, including cases of elevated $\mathrm{PM}_{10}$ concentrations relative to the concentration in the free atmosphere.

To understand how strongly inversions trap pollutants, a comparison was made between the simulated background concentrations in the air above the inversions (typically around $1 \mathrm{~km}$ ) to the simulated value close to the water surface. We then compared the simulated near-surface concentrations with data from the Interagency Monitoring of Protected Visual Environments (IMPROVE) network sites in Alaska to further assess the conditions in Glacier Bay. Note that this network monitors air quality in remote, federally protected Class I areas set forth by the Regional Haze Rule, i.e. areas of pristine air conditions.

\section{Results and Discussion}

\subsection{Evaluation}

\subsubsection{Surface Observations}

While WRF/Chem adequately captured the near-surface meteorology throughout the 124-day tourist season, similar to many other high-latitude studies (e.g. [4] [26] [30] [31]), it failed in some instances to capture the atmospheric dynamics when conditions were changing rapidly, or over complex terrain.

WRF/Chem sufficiently captured the temporal evolution of $2 \mathrm{~m}$ air temperature, (Figure 3(a)) although it underestimated the values slightly, resulting in a cold bias of $-0.6 \mathrm{~K}$ (Table 1). Hourly temperatures were well correlated at $\mathrm{r}=0.70$, with a RMSE of $2.5 \mathrm{~K}$ and SDE of $2.4 \mathrm{~K}$. The spatial standard deviation of simulated and observed temperature was $3.0 \mathrm{~K}$ and $3.1 \mathrm{~K}$, respectively, meaning WRF/Chem also captured the spatial distribution well. Overall, skill scores were slightly better, or within the range of other high latitude studies that have used WRF or WRF/Chem [30] [32]. The small errors in $2 \mathrm{~m}$ air temperature may be due to misrepresentation of terrain height and land-use type, as well as the choice of empirical parameters and parameterizations.

WRF/Chem also captured the temporal evolution of dew-point temperature well (Figure 3(b)). Hourly values were correlated strongly $(\mathrm{r}=0.83)$, with a marginal dry bias $(-0.2 \mathrm{~K})$. RMSE and SDE were both $2 \mathrm{~K}$. Spatial standard deviations of simulated and observed values were $3.3 \mathrm{~K}$ and $3.4 \mathrm{~K}$, respectively. The errors most likely were the result of misrepresentation of land-use or soil type, terrain height, or incorrect sea-surface temperatures.

WRF/Chem consistently overestimated wind speed for almost all locations (Figure 3(c)) with a $1.75 \mathrm{~m} \cdot \mathrm{s}^{-1}$ bias, but captured the temporal evolution of wind speed well. The latter was especially prominent when observed winds exceeded $4 \mathrm{~m} \cdot \mathrm{s}^{-1}$. Mean simulated and observed wind speeds were about $4.4 \pm 2.7 \mathrm{~m} \cdot \mathrm{s}^{-1}$ and $2.6 \pm$ $2.7 \mathrm{~m} \cdot \mathrm{s}^{-1}$, respectively. RMSE and SDE were $3.34 \mathrm{~m} \cdot \mathrm{s}^{-1}$ and $2.84 \mathrm{~m} \cdot \mathrm{s}^{-1}$, respectively. The daily (hourly) data were only moderately correlated at $r=0.51(r=0.44)$ due to 1$)$ slight errors in timing of frontal passages, and 2) local effects (channeling, wind shadows, etc.) that are inherent in the observation, but of subgrid-scale with respect to the model. 
Daily Average Temperature

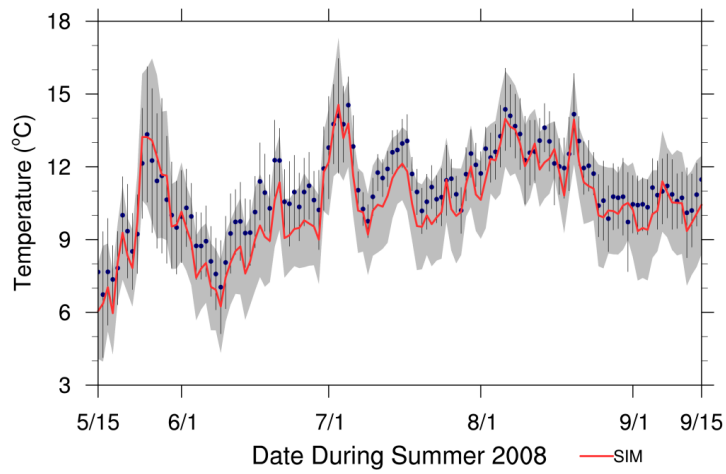

(a)

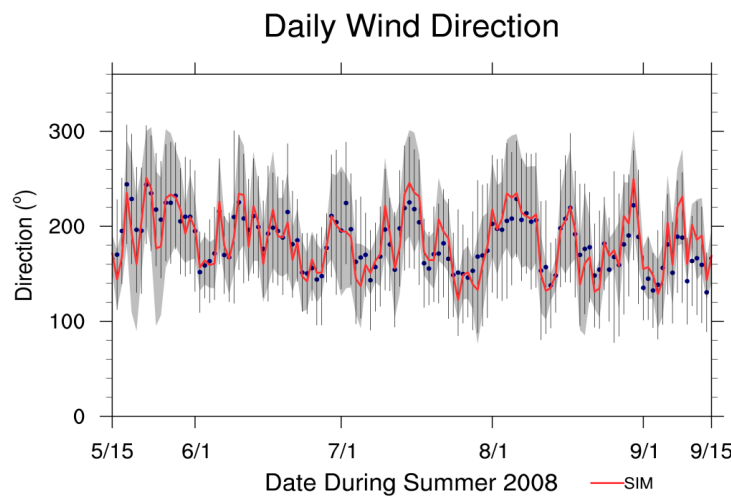

(c)

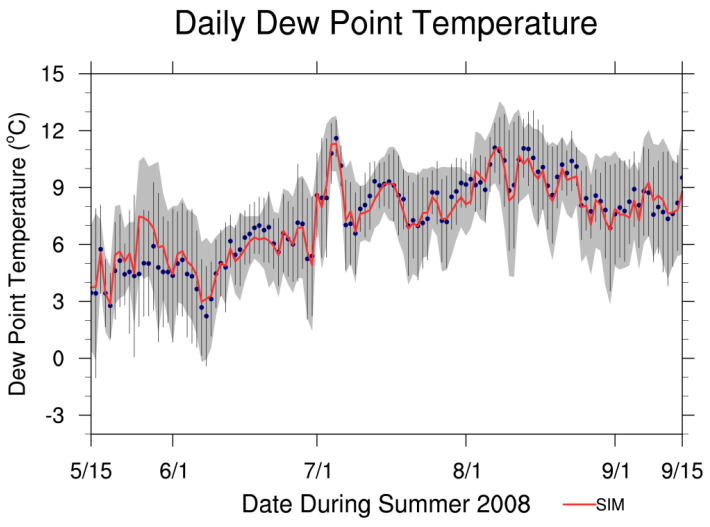

(b)

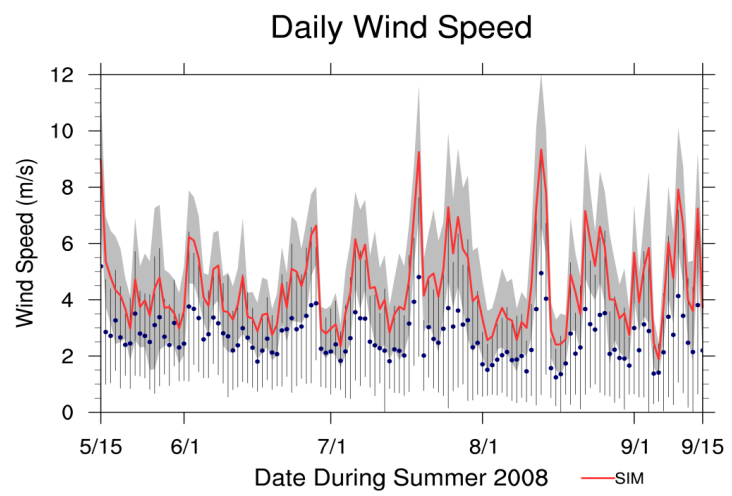

(d)

Figure 3. Time series plots illustrating (a) daily average temperature; (b) dew-point temperature; (c) wind speed; and (d) wind direction from the 42 sites in the domain during the 2008 tourist season. Blue polymarkers indicate the average observed value, the red line is the average simulated WRF/Chem value, and the gray shading is the spatial standard deviation averaged for all sites.

General changes in the wind direction were also captured by WRF/Chem. Winds in Southeast Alaska generally fluctuated between $150^{\circ}-250^{\circ}$ due to the prevailing flow from storm systems over the Gulf of Alaska. The mean simulated and observed wind direction was $182^{\circ}$ and $178^{\circ}$, respectively, resulting in a positive bias of $2^{\circ}$. Daily RMSE and SDE were $66^{\circ}$ and $59^{\circ}$, respectively. These skill scores are consistent with other WRF studies in high latitudes [30]-[32].

Despite only 24 sites recorded sea-level pressure, simulated and observed pressures were extremely well correlated $(r=0.996)$. The hourly mean simulated (observed) pressure was $1013.97 \mathrm{hPa} \pm 6.50 \mathrm{hPa}(1014.86 \pm 6.79$ $\mathrm{hPa})$.

\subsubsection{Radiosondes}

The evaluation considered 244 radiosonde ascents. Two days worth of data were missing, and no data existed between approximately $506 \mathrm{~m}$ to $716 \mathrm{~m}$ as the local terrain conditions prohibited receiving signals from these heights. The focus was on WRF/Chem's performance in simulating temperature, dew-point temperature, wind speed, and wind direction below $2 \mathrm{~km}$, as we were particularly interested in WRF/Chem's performance in the ABL.

In general, the model captured most of the observed profile characteristics (Figures 4(a)-(d)). Simulated and observed temperature profiles were well correlated at an average of $r=0.85$ (Table 2). WRF/Chem had a marginal overall warm bias of $0.1 \mathrm{~K}$, and low RMSE of $1.8 \mathrm{~K}$. Air temperatures were generally underestimated by $-1.4 \mathrm{~K}$ to $-0.3 \mathrm{~K}$ in heights below $600 \mathrm{~m}$. The surface layer had highest bias $(-1.4 \mathrm{~K})$ and lowest correlation $(\mathrm{r}=$ 0.68), probably due to misrepresentation of the surface conditions (topography, land-use, soil type). Simulated temperatures followed the temporal evolution of the upper air-temperature profiles with slight, but consistent 
Table 1. Skill scores summarizing the simulated and observed meteorological data. The data compares the average \pm standard deviation of modeled and observed quantities, as well as quantitative skill scores: root mean square error (RMSE), standard deviation error (SDE), bias, and correlation. Variables include average temperature (T), dew-point temperature $\left(T_{d}\right)$, relative humidity (RH), sea-level pressure (SLP), wind speed (v), and wind direction (Dir). Skill scores are displayed hourly (1 h) and daily (24 h) for the tourist season (May 15 to September 15, 2008).

\begin{tabular}{|c|c|c|c|c|c|c|}
\hline & \multicolumn{6}{|c|}{ Hourly seasonal } \\
\hline & Simulated & Observed & RMSE & SDE & Bias & Correlation \\
\hline $\mathrm{T}\left({ }^{\circ} \mathrm{C}\right)$ & $10.4 \pm 3.0$ & $11.1 \pm 3.1$ & 2.5 & 2.4 & -0.6 & 0.70 \\
\hline $\mathrm{T}_{\mathrm{d}}\left({ }^{\circ} \mathrm{C}\right)$ & $7.2 \pm 3.4$ & $7.4 \pm 3.3$ & 2.0 & 2.0 & -0.2 & 0.83 \\
\hline RH (\%) & $79 \pm 16$ & $77 \pm 16$ & 13 & 13 & 2 & 0.66 \\
\hline SLP (hPa) & $1013.97 \pm 6.50$ & $1014.86 \pm 6.79$ & 1.11 & 0.93 & -0.89 & $\sim 1$ \\
\hline $\mathrm{v}\left(\mathrm{m} \cdot \mathrm{s}^{-1}\right)$ & $4.40 \pm 2.74$ & $2.64 \pm 2.60$ & 3.34 & 2.84 & 1.75 & 0.44 \\
\hline \multirow[t]{3}{*}{$\operatorname{Dir}\left({ }^{\circ}\right)$} & $181 \pm 83$ & $171 \pm 93$ & 97 & 95 & 10 & 0.36 \\
\hline & \multicolumn{6}{|c|}{ Daily seasonal } \\
\hline & Simulated & Observed & RMSE & SDE & Bias & Correlation \\
\hline $\mathrm{T}\left({ }^{\circ} \mathrm{C}\right)$ & $10.4 \pm 2.5$ & $11.0 \pm 2.2$ & 2.0 & 1.9 & -0.6 & 0.69 \\
\hline $\mathrm{T}_{\mathrm{d}}\left({ }^{\circ} \mathrm{C}\right)$ & $7.2 \pm 3.3$ & $7.4 \pm 3.1$ & 1.65 & 1.6 & -0.2 & 0.87 \\
\hline RH (\%) & $80 \pm 14$ & $78 \pm 12$ & 10 & 10 & 2 & 0.71 \\
\hline SLP (hPa) & $1013.97 \pm 6.30$ & $1014.86 \pm 6.58$ & 1.04 & 0.87 & -0.89 & $\sim 1$ \\
\hline $\mathrm{v}\left(\mathrm{m} \cdot \mathrm{s}^{-1}\right)$ & $4.45 \pm 2.21$ & $2.69 \pm 2.12$ & 2.78 & 2.15 & 1.77 & 0.51 \\
\hline $\operatorname{Dir}\left({ }^{\circ}\right)$ & $182 \pm 63$ & $178 \pm 67$ & 66 & 59 & 2 & 0.45 \\
\hline
\end{tabular}

Table 2. Averaged overall statistics for temperature, dew-point temperature, wind speed and wind direction from the simulated and observed upper air profiles at Yakutat.

\begin{tabular}{ccccc}
\hline & Temperature $\left({ }^{\circ} \mathrm{C}\right)$ & Dew-point temperature $\left({ }^{\circ} \mathrm{C}\right)$ & Wind speed $\left(\mathrm{m} \cdot \mathrm{s}^{-1}\right)$ & Wind direction $\left({ }^{\circ}\right)$ \\
\hline Mean WRF/Chem & -14.2 & -21.1 & 10.12 & 194 \\
Mean radiosonde & -14.3 & -21.9 & 10.12 & 0.66 \\
Correlation (R) & 0.85 & 0.60 & 0.69 & -12 \\
Bias & 0.1 & 0.8 & $\sim 0$ & -56 \\
Bias Min & -1.4 & -6.4 & -1.44 & -3 \\
Bias Max & 0.8 & 3.5 & 1.18 & 9 \\
RMSE & 1.8 & 4.6 & 4.13 & 0 \\
RMSE Min & 1.2 & 1.6 & 2.19 & 20 \\
RMSE Max & 2.6 & 11.3 & 8.64 & 9 \\
SDE & 1.8 & 5.0 & 4.21 & 9 \\
SD WRF/Chem & 1.8 & 2.2 & 2.41 & 9 \\
SD radiosonde & 1.8 & 2.2 & 2.38 & 9 \\
\hline
\end{tabular}

variations and low errors over the entire profile. Simulated and observed variance of the profiles agreed well with values of $3.1 \mathrm{~K}^{2}$ and $3.2 \mathrm{~K}^{2}$, respectively.

WRF/Chem generally simulated the dew-point temperature profiles (Figure 4(b)) well in levels closest to the 


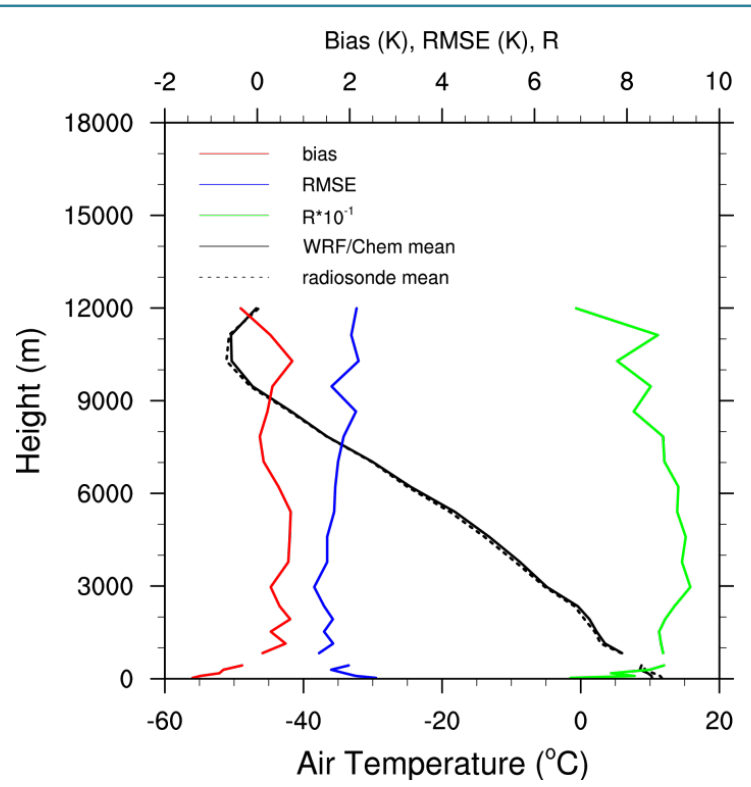

(a)

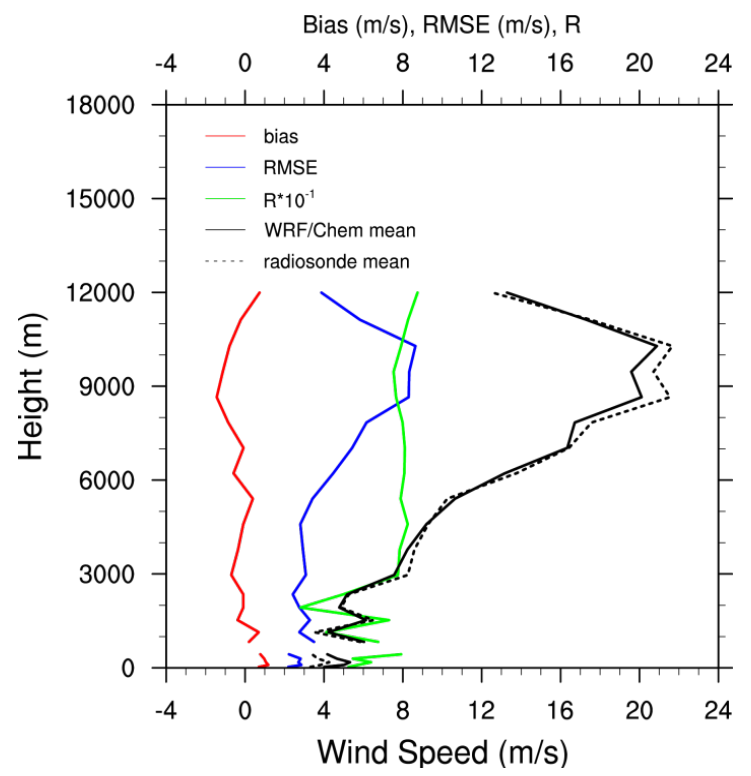

(c)

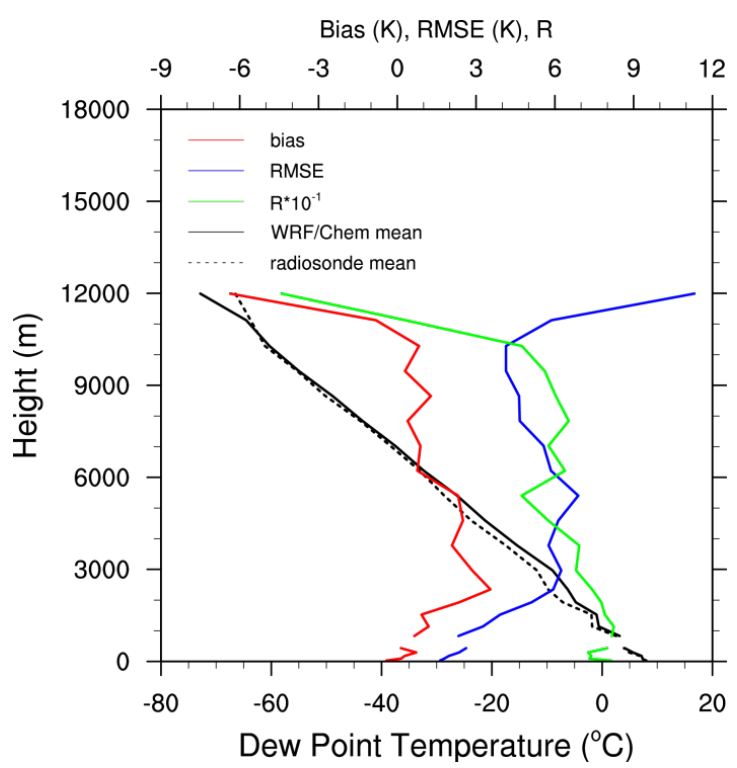

(b)

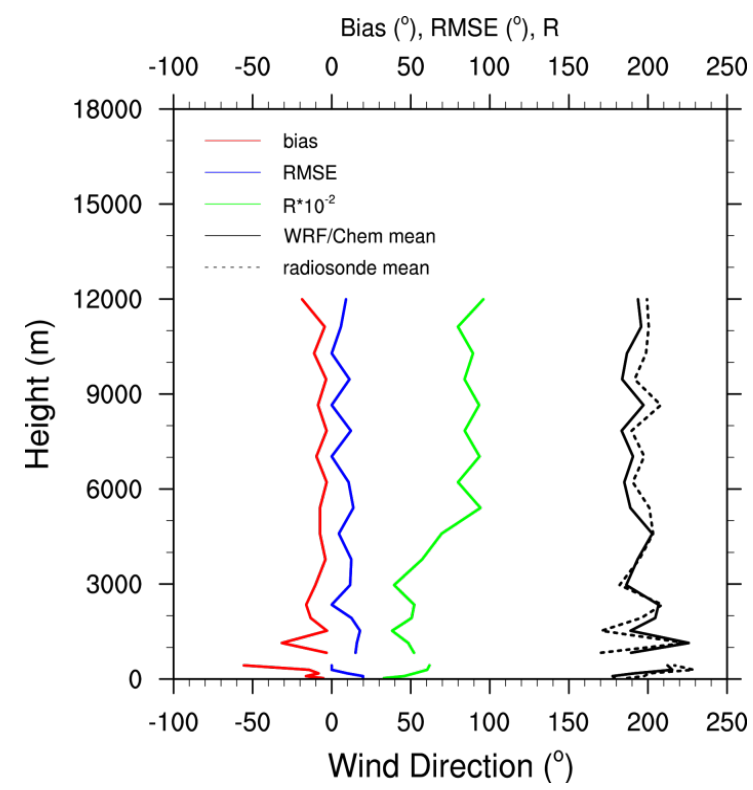

(d)

Figure 4. Correlation (R), bias, RMSE, and mean WRF/Chem simulated and observed air-temperature, dew-point temperature, wind-speed, and wind-direction profiles in Yakutat, AK from May 15 to September 15, 2008. The correlation is scaled by a factor of ten on the temperature, dew-point temperature, and wind-speed plots, and by 100 on the wind-direction plot. The RMSE, bias, and correlation scales are displayed on the top x-axis. The small gap around $500-700 \mathrm{~m}$ accounts for missing radiosonde observations.

ground. The correlation between simulated and observed profiles $(r>0.70)$ was best below $4600 \mathrm{~m}$ and slightly dropped off to around $r \approx 0.5$ near the tropopause. Here, WRF/Chem had difficulties in simulating the dew-point temperature in areas of strong wind shear. Another region of strong wind shear existed from $1500-3000 \mathrm{~m}$, when wind direction shifted rapidly between south-southeast to southwest. WRF/Chem captured the dew-point trend, but slightly overestimated it, meaning a slight wet bias.

WRF/Chem generally overestimated the overall dew point-temperature profile marginally with biases from 0.2 to $1.2 \mathrm{~K}$ below $1500 \mathrm{~m}$, to as high as $3.6 \mathrm{~K}$ around regions of strong wind shear $\left(>40^{\circ}\right)$. Variances of simulated and observed dew-point temperatures agreed excellently $\left(4.9 \mathrm{~K}^{2}\right.$ vs. $\left.5.0 \mathrm{~K}^{2}\right)$. The low vertical resolution of 
the initialization data, the low density of the radiosonde network in Alaska and Northwest Canada which was used as input for the creation of the analysis data, and a wet or iced over sensor after passing through a cloud, are all potential error sources (e.g. [29] [33]).

The upper air wind-speed profiles (Figure 4(c)) were accurately captured, but WRF/Chem had some difficulties below $2500 \mathrm{~m}$. The overall wind-speed correlation was $r=0.69$. The highest correlations occurred above $3000 \mathrm{~m}$ where the magnitudes of shear and windspeed variability were least. Simulated and observed regions of wind shear matched well (Figure 4(d)). WRF/Chem overestimated wind speeds by $0.2-1.2 \mathrm{~m} \cdot \mathrm{s}^{-1}$ from the surface to about $1100 \mathrm{~m}$, and marginally underestimated the wind speeds above this level to the tropopause. Generally, wind-speed biases (simulated minus observed) remained less than $0.7 \mathrm{~m} \cdot \mathrm{s}^{-1}$ in levels close to the surface. The overall mean simulated and observed wind speeds were exactly $10.1 \mathrm{~m} \cdot \mathrm{s}^{-1}$, resulting in a mean bias of nearly zero due to compensation of positive and negative differences. WRF/Chem also simulated the wind-speed variance well $\left(5.80 \mathrm{~m}^{2} \cdot \mathrm{s}^{-2}\right.$ vs. $\left.5.67 \mathrm{~m}^{2} \cdot \mathrm{s}^{-2}\right)$. When we assume that the temporal standard deviation is representative for the daily variability, WRF/Chem and the observations also show the same vertical mean variability of about $2.4 \mathrm{~m} \cdot \mathrm{s}^{-1}$.

The discrepancies between simulated and observed wind data can partly be explained by radiosonde drift during the ascent [34], the different terrain height in the model and real world, different vertical resolution of the model and observations, and measurement errors.

Depending on the meteorological conditions and cruise-ship type, the emissions are ejected anywhere between 52 and nearly $200 \mathrm{~m}$ height above sea-level. Thus, the overestimation of wind speeds in the lower decameter above ground may lead to faster dispersion than compared to the real world. The underestimations around the tropopause, however, are irrelevant for the dispersion of particulate matter from cruise-ship emissions.

The overall mean WRF/Chem simulated and radiosonde-reported wind directions were $198^{\circ} \pm 9^{\circ}$ and $194^{\circ} \pm$ $9^{\circ}$, respectively, leading to an average bias of $-12^{\circ}$. WRF/Chem responded well to wind-direction changes, but often fell short by a few degrees. Simulated and observed wind directions correlated well $(r=0.66$ overall) except in regions of high wind shear and rapidly fluctuating directions. Near the surface, WRF/Chem underestimated wind direction by $12^{\circ}$.

The volume integral for velocity is identical to the measured values (Table 2). This means that WRF captured these quantities excellently, but the simulated and observed spatial distributions of velocities differ vertically. Positive and negative biases cancelled each other out over the entire volume (cf. Figure 4).

According to the WRF/Chem simulations, 106 of the profiles at the times of radiosonde ascent showed surface inversions, while 97 surface inversions were observed, i.e. WRF/Chem overestimated the frequency of surface inversion occurance by $9 \%$. WRF/Chem predicted 77 elevated inversions, while the ascents showed 82 . This means it underestimated the occurance of elevated inversions by about $12 \%$. Given the vertical resolution of WRF/Chem and the radiosonde measurements, as well as the very good performance of WRF/Chem in simulating the air-temperature profiles in the ABL, we consider these discrepancies acceptable for making inferences about the nature of inversions and their role in driving the fate of pollutants in Glacier Bay.

\subsection{Fate of Particulate Matter in Glacier Bay}

Overall, air quality in Glacier Bay was relatively pristine even in the presence of cruise-ships. The U.S. Environmental Protection Agency's (EPA) 24-hour daily average National Ambient Air Quality Standard (NAAQS) value for $\mathrm{PM}_{10}$ is set to not exceed $150 \mu \mathrm{g} \cdot \mathrm{m}^{-3}$, otherwise the quality of air is deemed to be unhealthy, and may lead to nonattainment if consistently exceeded [35]. We use these EPA values as a benchmark in weighting the severity of $\mathrm{PM}_{10}$ in relation to pollution levels in other parts of the United States. In Glacier Bay, the WRF/ Chem-derived daily averages of $\mathrm{PM}_{10}$ were well below $150 \mu \mathrm{g} \cdot \mathrm{m}^{-3}$. However, there were occasions when hourly concentrations approached $50 \mu \mathrm{g} \cdot \mathrm{m}^{-3}$. When $\mathrm{PM}_{10}$ values are elevated and relative humidity is high $(>80 \%)$, the particles swell and tend to reduce visibility [2]. Thus, even though NAAQS values were never exceeded there were periods when visibility was likely reduced due to cruise-ship emissions and haze formation [2] like is shown in the example in Figure 1.

The WRF/Chem simulations also demonstrated that in Glacier Bay, $\mathrm{PM}_{10}$ concentrations stemming from gas-to-particle conversion of naturally available trace gases and/or sea salts were generally below $1-2 \mu \mathrm{g} \cdot \mathrm{m}^{-3}$, i.e. in the range of the typically observed background concentrations. Data from the Alaska Class I area IMPROVE sites, which tend to reflect regions of pristine air quality, showed concentrations of similar or higher 
magnitude during summer when no wildfires were reported nearby.

The WRF/Chem simulations showed that synoptic scale weather disturbances and mesoscale phenomena during weak synoptic scale forcing governed the fate of pollutants in Glacier Bay. In the majority of cases, the former moved pollutants out of Glacier Bay, while during the latter, inversions and local circulations formed.

Inversions commonly developed through subsidence under synoptic scale high-pressure systems, or due to radiative cooling under calm wind weak synoptic forcing. Due to its latitudinal position and topography, Glacier Bay still has at least five to seven hours with little to no incoming solar radiation, with the longest period of insolation around solstice (June 21). However, the low sun altitude and tall mountains may hinder direct insolation. The mean long-wave radiation loss was $-328 \mathrm{Wm}^{-2}$ during nighttime and early morning hours when inversions most commonly developed.

Strong inversions of greater than $2 \mathrm{~K}(100 \mathrm{~m})^{-1}$ appeared to notably trap ship emissions, which resulted in up to a $43 \%$ increase in $\mathrm{PM}_{10}$ concentrations compared to cases with no inversions present. Throughout the tourist season, the simulated average inversion strength and height over Glacier Bay was $1.2 \mathrm{~K}(100 \mathrm{~m})^{-1}$ and $92.5 \mathrm{~m}$, respectively. While some of the inversions were not strong enough to appreciably trap cruise-ship pollutants, some inversion gradients were as strong as $6.7 \mathrm{~K}\left(100 \mathrm{~m}^{-1}\right.$. Spatially, most inversions occurred in the middle and entrance regions of Glacier Bay where it is approximately 10 - $25 \mathrm{~km}$ wide. Consequently, inversions occurring in these portions of Glacier Bay are of resolvable scale with respect to WRF/Chem's horizontal resolution in this study, as opposed to other fjord locations that are subgrid-scale.

While it is insightful to consider seasonal average conditions, it is equally relevant to identify conditions when the highest concentrations were simulated inside Glacier Bay as 1) these are conditions when ecosystems and visitor experience may be most impacted, and 2) park management may want to make decisions not on seasonal averages, but on peak (extreme) conditions. We also describe three cases that exemplified the conditions that led to a persistence of elevated $\mathrm{PM}_{10}$ concentrations.

\subsubsection{Strongest $P M_{10}$ Concentration}

In 2008, the most extreme $\mathrm{PM}_{10}$ event during the 124-day tourist season occurred on July 19 (Figure 5). Two cruise-ships entered the park that day, which is typical for Glacier Bay. The NPS does not allow more than two ships to enter the park on a daily basis and the daily average was approximately 1.4 ship entries per day in 2008 . The simulation indicated inversions in multiple locations of Glacier Bay. Figure 5 shows the 24-hour temporal evolution of $\mathrm{PM}_{10}$ and wind throughout that day. A weak stationary front was located off the coast of southeast Alaska on July 19, 0000 UTC (1500 LT July 18). Winds began relatively light, generally less than $5.1 \mathrm{~m} \cdot \mathrm{s}^{-1}(10$ knots), and increased to about $10.3 \mathrm{~m} \cdot \mathrm{s}^{-1}$ (20 knots) from the southeast during the day. The air was fairly clean $\left(<6 \mu \mathrm{g} \cdot \mathrm{m}^{-3}\right)$, but elevated $\mathrm{PM}_{10}$ concentrations were evident by $0500 \mathrm{UT}$ (2000 LT). Concentrations $>44 \mu \mathrm{g} \cdot \mathrm{m}^{-3}$ occurred in the Cross Sound, and over the eastern Gulf of Alaska. The locations of major geographical locations can be found in Figure 1. In addition, all contour plots are oriented with north toward the top center of the figure.

As the stationary front shifted further east throughout the day, wind direction shifted towards the south and southwest. Advection of pollutants originating from cruise-ships just outside of Glacier Bay may have contributed to those elevated $\mathrm{PM}_{10}$ concentrations. By 1500 UT (0600 LT), the entrance of both cruise-ships kept the $\mathrm{PM}_{10}$ concentrations at about $18 \mu \mathrm{g} \cdot \mathrm{m}^{-3}$ for at least nine hours, as the spatial distribution of $\mathrm{PM}_{10}$ in the park was associable with the route taken by the ships. Especially high concentrations were evident towards the middle of Glacier Bay, as well as in the Northwest Fork, since both cruise-ships had to pass though the middle of the bay twice, and both cruise-ships spent time at berth in the Northwest Fork for glacier viewing. While this route and period of time spent in the upper fjord is standard for cruise-ships entering Glacier Bay, ship emissions occurred when an inversion existed very close to the surface on this day. Consequently, the daily average $\mathrm{PM}_{10}$ concentration close to the surface was $20.5 \mu \mathrm{g} \cdot \mathrm{m}^{-3}$ while the concentration above the inversion levels was $6.6 \mu \mathrm{g} \cdot \mathrm{m}^{-3}$. Approximately $400 \mathrm{~m}$ above that level, $\mathrm{PM}_{10}$ concentration diminished to $3.1 \mu \mathrm{g} \cdot \mathrm{m}^{-3}$.

While the high $\mathrm{PM}_{10}$ concentrations inside Glacier Bay may have partly resulted due to advection from other cruise-ships passing near Glacier Bay in the Gulf of Alaska or waterways just to the south of the park (Icy Strait), the high daily average $\mathrm{PM}_{10}$ concentrations (up to $22 \mu \mathrm{g} \cdot \mathrm{m}^{-3}$ in some parts of the bay) was consistent with the ships emitting pollutants that were then trapped in the park from the inversions. Note that regions of the bay with no inversions allowed the pollutants to mix to higher levels in the ABL, which explains why the 

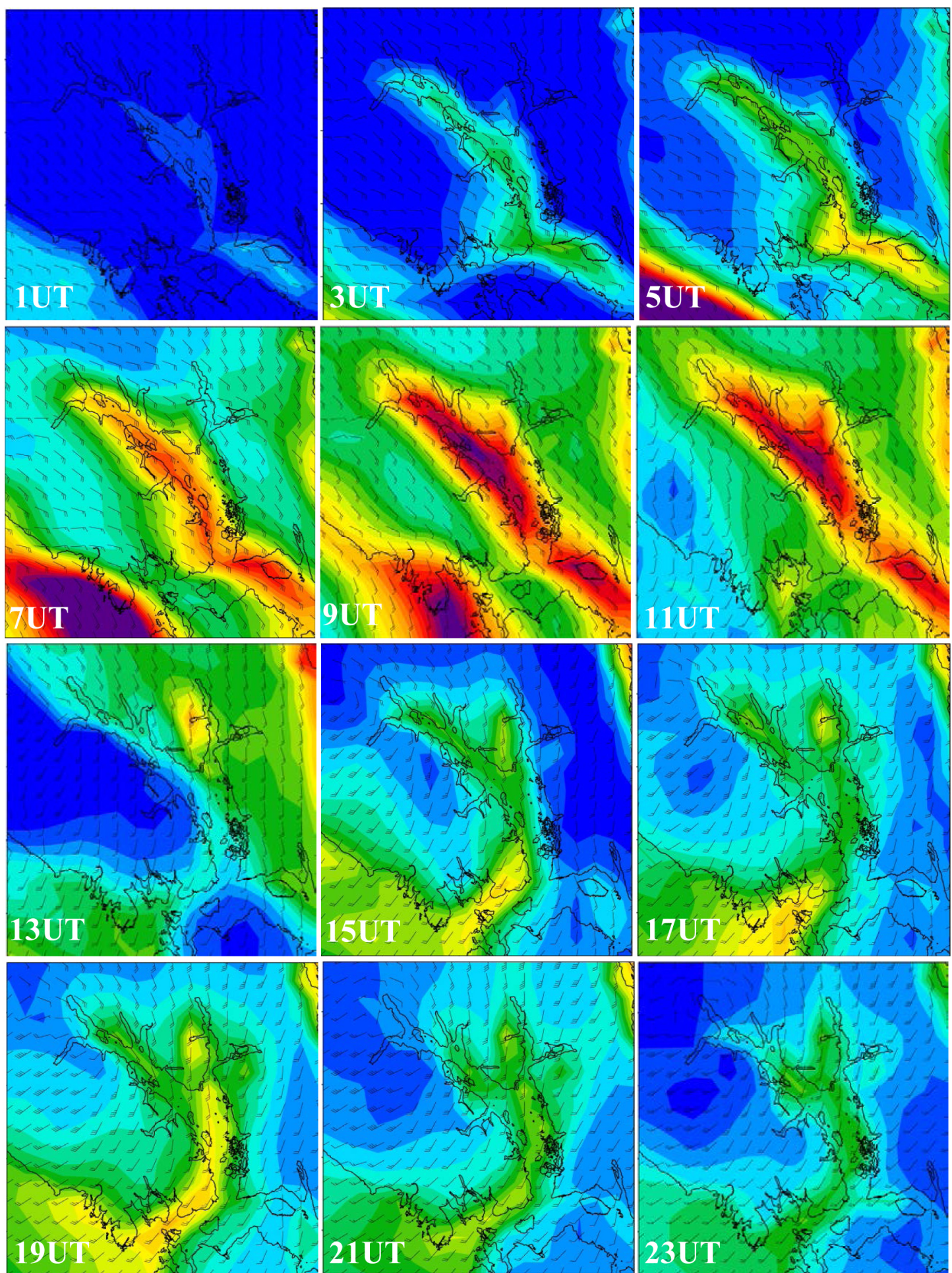

$\mathrm{PM}_{10}$ Concentration $\left(\mu \mathrm{g} / \mathrm{m}^{3}\right)$

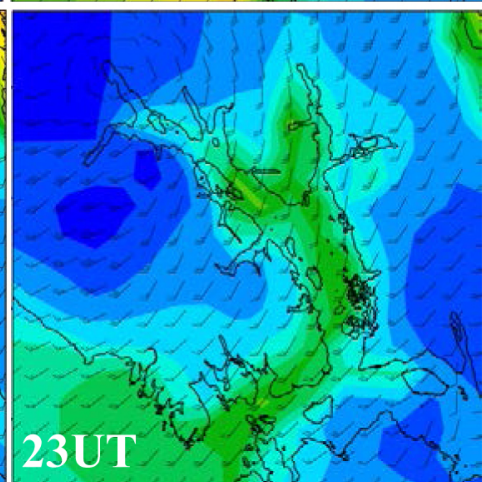

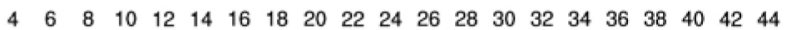

Figure 5. Zoomed-in plots showing the temporal evolution of $\mathrm{PM}_{10}$ in Glacier Bay on July 19, 2008. The panel plot depicts the "worst case event" of $\mathrm{PM}_{10}$ during the 2008 tourist season. There were two cruise-ship entrances, which is the maximum daily allowance set forth by the NPS. Synoptically, weather was calm with short-lived inversions in some parts of the bay. All plots in this figure have the same color scale. 
the background concentrations were slightly elevated there.

\subsubsection{Typical Case with Inversions and Two Ship Entries}

The simulations for May 27-28 exhibited a typical scenario of high $\mathrm{PM}_{10}$ concentrations and strong inversions inside Glacier Bay (Figure 6). Concentrations of $\mathrm{PM}_{10}$ began high $\left(>20 \mu \mathrm{g} \cdot \mathrm{m}^{-3}\right)$ early in the day, especially in the Gulf of Alaska. At 0500 LT, winds were calm inside most of the park, especially in sheltered locations. Wind speeds increased to $7.7-10.3 \mathrm{~m} \cdot \mathrm{s}^{-1}$ (15 - $\left.20 \mathrm{knots}\right)$ in the open waters of the Gulf of Alaska. Two cruise-ships entered Glacier Bay, while three additional ships passed in the vicinity of the park without entering. Some advection of pollutants occurred through Icy Strait, and by 1500 LT, $\mathrm{PM}_{10}$ concentrations rose notably, especially towards the park entrance $\left(12-14 \mu \mathrm{g} \cdot \mathrm{m}^{-3}\right)$.

As midnight approached, particulates largely dispersed once the cruise-ships departed Glacier Bay. However, residual $\mathrm{PM}_{10}$ from earlier in the day (approximately $6-8 \mu \mathrm{g} \cdot \mathrm{m}^{-3}$ ) remained trapped under persistent inversions. With weak $\left(<2.57 \mathrm{~m} \cdot \mathrm{s}^{-1}\right.$ (5 knots)) to no winds inside Glacier Bay, the $\mathrm{PM}_{10}$ did not propagate further into the bay. The average inversion height and strength was $1.24 \mathrm{~K}(100 \mathrm{~m})^{-1}$ and $129.2 \mathrm{~m}$, respectively. Inversions were strong (up to $6.7 \mathrm{~K}(100 \mathrm{~m})^{-1}$ ) and thick during this event, spanning up to $400 \mathrm{~m}$, especially in locations close to the park entrance. This feature is indicative of a subsidence inversion, as result of a stable marine boundary layer.

The average $\mathrm{PM}_{10}$ concentration close to the surface was approximately $10.3 \mu \mathrm{g} \cdot \mathrm{m}^{-3}$. Above any inversion levels of around $1 \mathrm{~km}, \mathrm{PM}_{10}$ concentrations rapidly diminished to pristine conditions of $1.4 \mu \mathrm{g} \cdot \mathrm{m}^{-3}$, indicating that strong inversions helped to contain pollutants.

\subsubsection{Case of Mesoscale Slope Breeze Circulation}

$\mathrm{PM}_{10}$ concentrations on May 19-20 (Figure 7) were influenced by three conditions. First, two cruise-ships entered and departed the park one after the other, which is common for many days in Glacier Bay. During the morning at 1600 UT (0700 LT), the air inside Glacier Bay was pristine with $\mathrm{PM}_{10}$ concentrations of $1-2 \mu \mathrm{g} \cdot \mathrm{m}^{-3}$ (Figure 7). The first cruise-ship reached the central part of the bay by 1000 LT and departed by 1600 LT. PM $_{10}$ dispersed for three hours. Evidence of $\mathrm{PM}_{10}$ from the next cruise-ship was present in Glacier Bay by $1900 \mathrm{LT}$.

Second, winds were coming from the north-northwest, i.e. from unpolluted areas. Thus, no advection of pollutants from areas outside Glacier Bay into the park occurred. The north-northwest wind direction largely prevented $\mathrm{PM}_{10}$ from areas of high ship traffic in the Gulf of Alaska from entering Icy Strait and $\mathrm{PM}_{10}$ did not penetrate into the upper parts of the fjord. Atmospheric conditions remained calm and clear in the Glacier Bay area, which permitted the formation of inversions, some which were particularly strong $\left(\geq 4.5 \mathrm{~K}(100 \mathrm{~m})^{-1}\right)$. Wind speeds were low (about $2.57 \mathrm{~m} \cdot \mathrm{s}^{-1}$ (5 knots)) throughout most parts of Glacier Bay, and the synoptic conditions kept inversions from dissipating. Thus, emitted $\mathrm{PM}_{10}$ remained close to the original emission location.

Third, the simulations suggested that a mesoscale slope breeze formed inside of Glacier Bay. By mid-afternoon, a mesoscale circulation developed as the sun heated the mountain surfaces. At $1600 \mathrm{LT}$, upslope winds on the westward facing mountains slopes led to the spreading of $\mathrm{PM}_{10}$, but its vertical ascent was largely restricted by the inversion level, effectively trapping the pollutants. A self-contained mesoscale circulation resulted, and WRF/Chem simulated a gentle counterclockwise flow of the winds, indicated by the red arrows on Figure 7 .

As the day progressed, the circulation changed into a more downsloping pattern, and by 0200 LT the radiation balance became negative. On the west side of the bay, a sagging of the isotherms indicated a cold pool formation. The wind barbs showed that winds were gently flowing down the mountain slopes. Given the meteorological conditions during this day, $\mathrm{PM}_{10}$ was originated primarily from cruise-ship emissions. Concentrations peaked around $12-14 \mu \mathrm{g} \cdot \mathrm{m}^{-3}$. By $0200 \mathrm{LT}$, the $\mathrm{PM}_{10}$ emission ended, but the inversion retained the pollutants through May 20.

The average $\mathrm{PM}_{10}$ concentration close to the surface during this event was approximately $4.8 \mu \mathrm{g} \cdot \mathrm{m}^{-3}$. Above the inversion around $1 \mathrm{~km}$, simulated concentrations rapidly diminished to pristine conditions of $0.9 \mu \mathrm{g} \cdot \mathrm{m}^{-3}$. Thus, the inversion trapped the pollutants and hindered air exchange with the pristine air aloft. Concurrently, the mesoscale slope breeze circulation redistributed the pollutants below the inversion.

\subsection{4. $\mathrm{PM}_{10}$ Advection}

On August 13-14 conditions in Glacier Bay resulted in the second highest simulated $\mathrm{PM}_{10}$ concentrations of the 

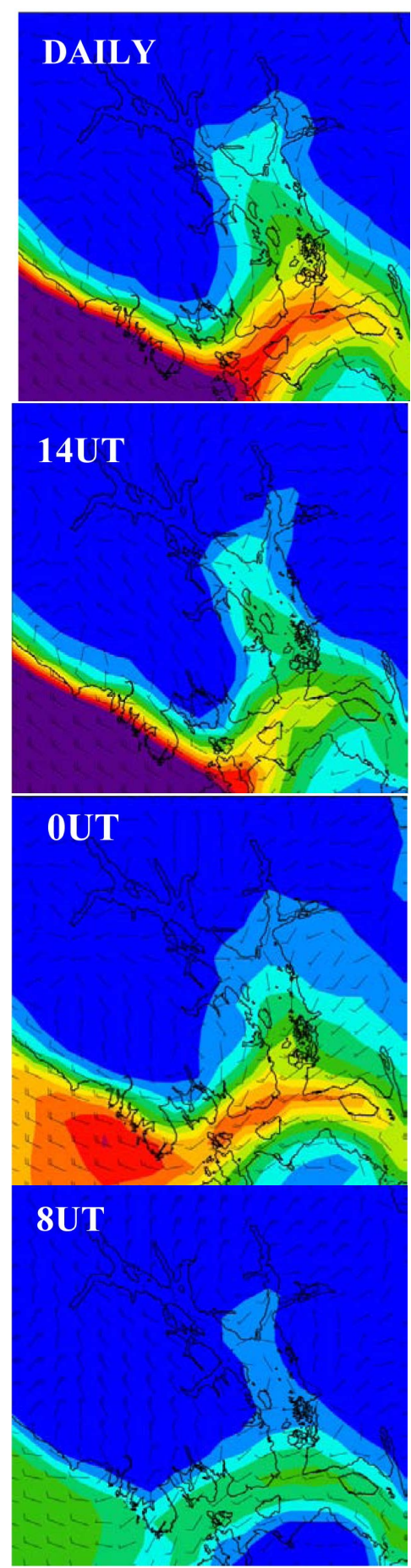

$\mathrm{PM}_{10}$ Concentration $\left(\mu \mathrm{g} / \mathrm{m}^{3}\right)$

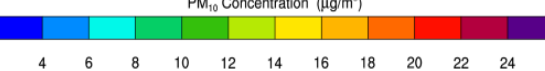

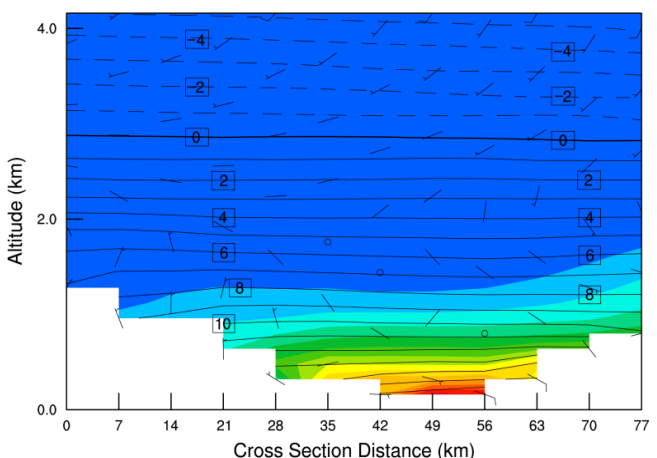
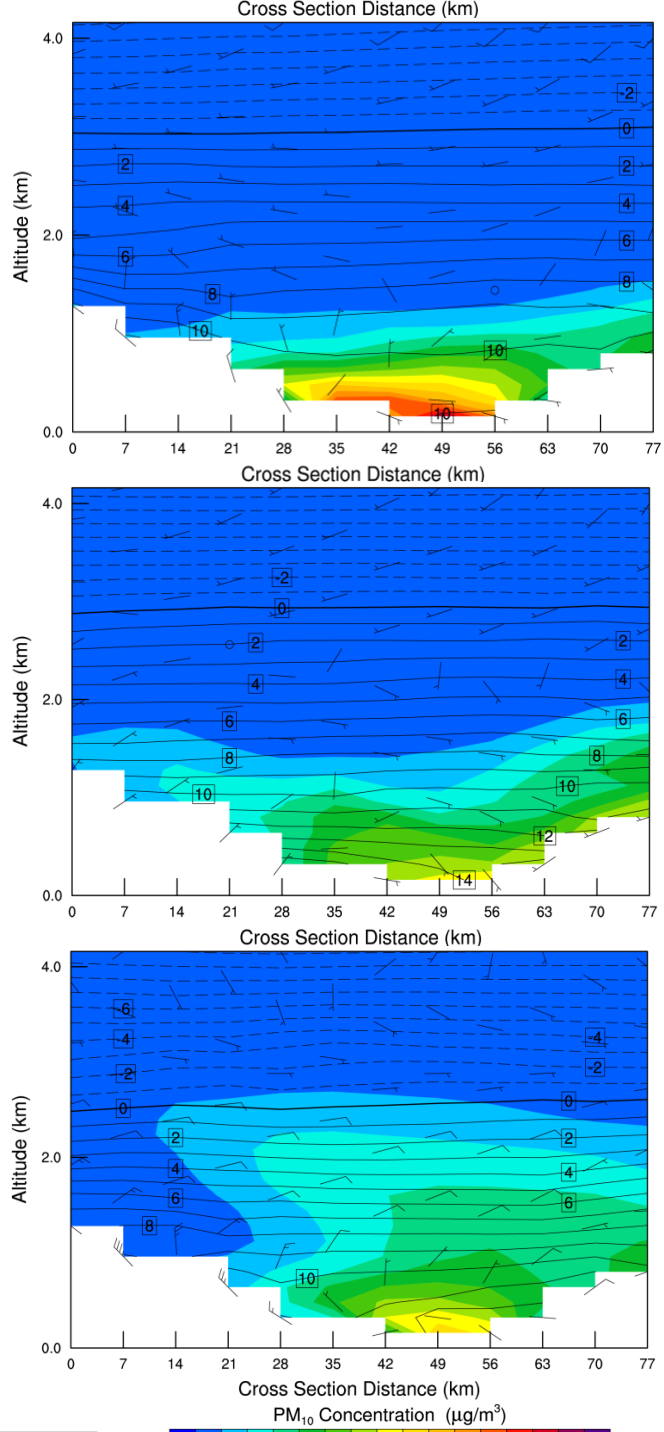

$\mathrm{PM}_{10}$ Concentration $\left(\mu \mathrm{g} / \mathrm{m}^{3}\right)$

$\begin{array}{lllllllllll}0 & 1 & 2 & 3 & 4 & 5 & 6 & 7 & 8 & 9 & 101112131415\end{array}$

Figure 6. May 27-28 case with inversions and two cruise-ship entries in Glacier Bay. The left colum shows zoomed-in contour plots depicting $\mathrm{PM}_{10}$ concentrations during selected hours of the day. The right column illustrates the corresponding cross section plot taken from horizontal transects across central Glacier Bay. The top row shows the daily average contour and cross section plots. The 14 UT plots show $\mathrm{PM}_{10}$ concentrations before ship entries with some particulate advection due to ships passing by. The 0 UT plots indicate the presence of a cruise-ship inside the bay. Winds are very calm, potentially indicative of a subsidence inversion. The final plots from 8 UT show $\mathrm{PM}_{10}$ after the cruise-ships have left Glacier Bay, with $\mathrm{PM}_{10}$ remaining trapped under stong inversions. All plots in each column have the same color scale. 

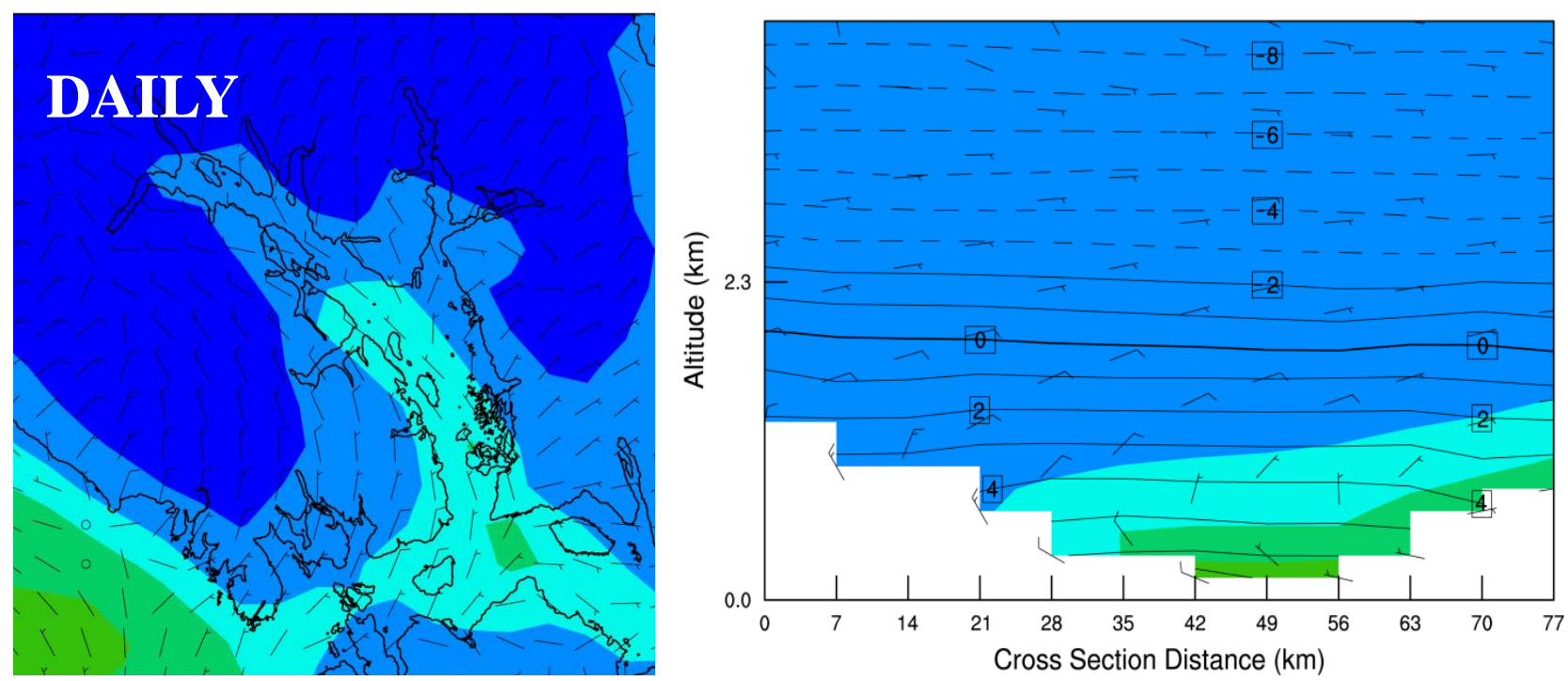

\section{UT}
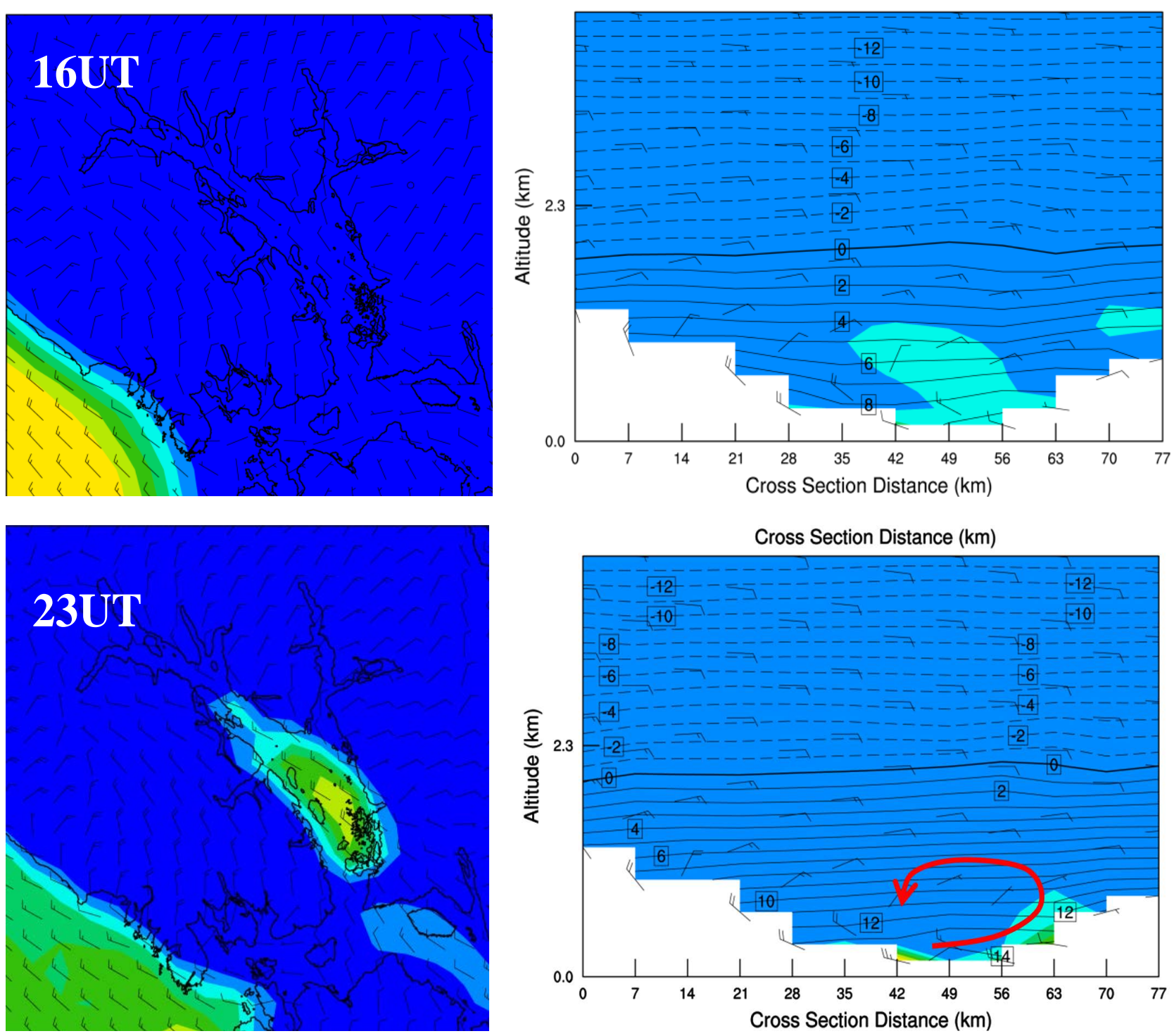

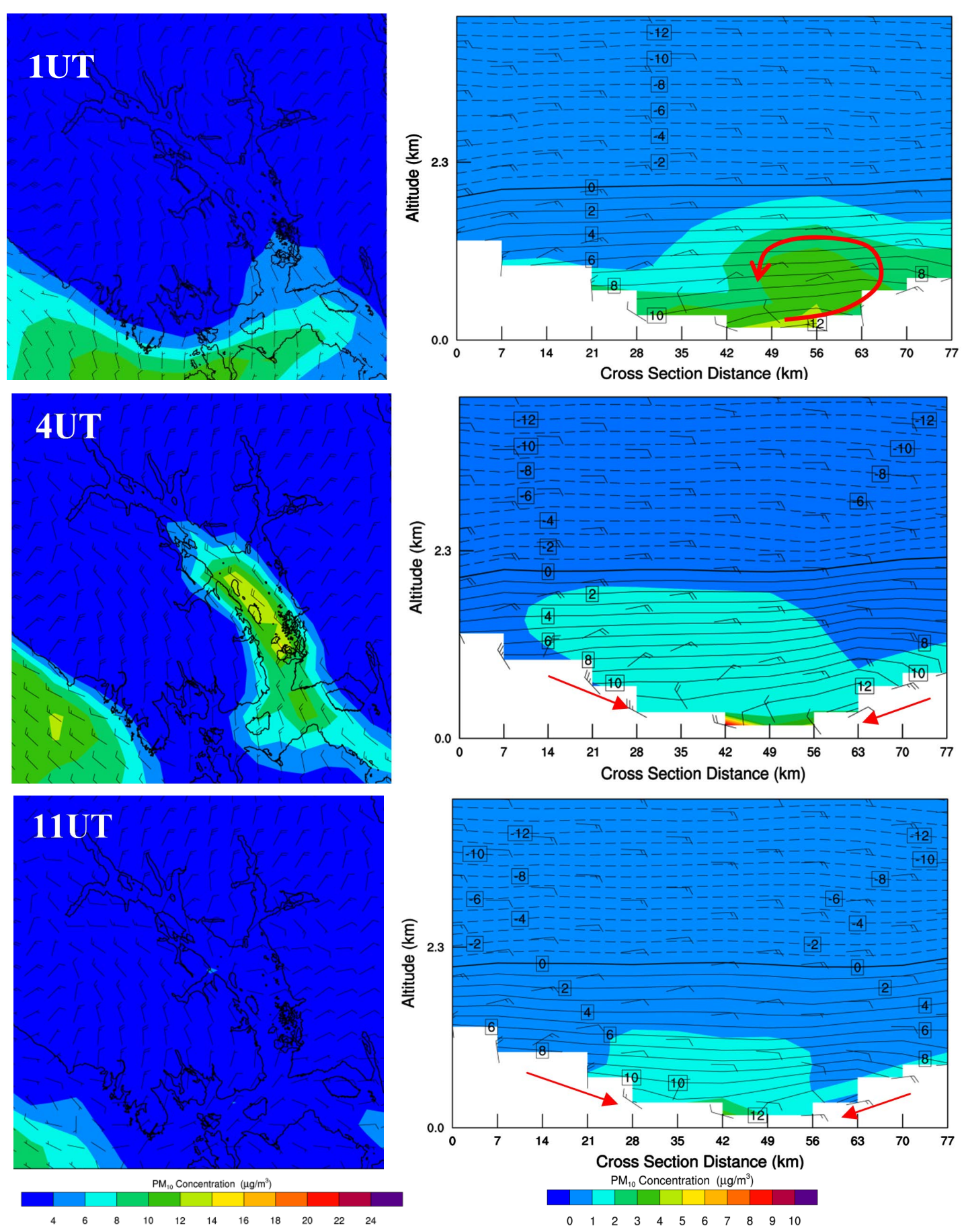

Figure 7. May 19-20 case of a mesoscale slope breeze in Glacier Bay. The left column shows zoomed-in contour plots depicting $\mathrm{PM}_{10}$ concentrations during selected hours of the day. The right column illustrates the corresponding cross section plot taken from horizontal transects across central Glacier Bay. The top row shows the daily average contour and cross section plots. The 16 UT plots shows pristine air before the cruise-ships entered. By 23 UT, the first cruise-ship enters, and a mesoscale upslope breeze begins to develop as a result of daytime heating on the sides of the mountain, leading to a gentle clockwise turning of the winds. At 1 UT, $\mathrm{PM}_{10}$ concentrations rise as the vertical ascent of polluted air within the mesoscale circulation is restricted by the presence of an inversion layer. By 4 UT, another cruise-ship is evident. Finally, by 11 UT, PM $_{10}$ concentrations gradually diminish. The mesocale circulation reverses, leading to slight downsloping winds and the development of a cold pool (where isotherms slightly sag). This cold pool formation typically occurs during nighttime hours with appreciable radiative cooling on the mountain slopes. All plots in each column have the same color scale. 
2008 tourist season (Figure 8) despite no inversions existed in Glacier Bay according to the WRF/Chem results. On August 13-14, $\mathrm{PM}_{10}$ concentrations in Glacier Bay were governed by windy conditions associated with a large $980 \mathrm{hPa}$ low-pressure system over the Gulf of Alaska. This storm resulted in intense orographic lifting. In most areas in Glacier Bay, average simulated concentrations of $\mathrm{PM}_{10}$ exceeded $15 \mu \mathrm{g} \cdot \mathrm{m}^{-3}$, and hourly values reached upwards of $24 \mu \mathrm{g} \cdot \mathrm{m}^{-3}$ by $1500 \mathrm{LT}$. During this episode, two cruise-ships entered the park and another cruise-ship passed through Icy Strait. $\mathrm{PM}_{10}$ concentrations exceeding $30 \mu \mathrm{g} \cdot \mathrm{m}^{-3}$ likely resulted from ship traffic in the Gulf of Alaska. Additionally, wind speeds were upwards of $12.9 \mathrm{~m} \cdot \mathrm{s}^{-1}$ (25 knots). Thus, sea spray associated with the strong wind may have also contributed to the elevated $\mathrm{PM}_{10}$ concentrations.

Concentrations of $\mathrm{PM}_{10}$ began elevated by $0200 \mathrm{LT}$ (up to $20 \mu \mathrm{g} \cdot \mathrm{m}^{-3}$ ), and the small $24 \mu \mathrm{g} \cdot \mathrm{m}^{-3}$ bull's-eye of $\mathrm{PM}_{10}$ off Pleasant Island near the entrance of Glacier Bay occurred in response to the emissions by a cruise-ship. Strong $12.9 \mathrm{~m} \cdot \mathrm{s}^{-1}$ (25 knots) winds from the southeast advected pollutants from Chatham Strait eastward. Advection of $\mathrm{PM}_{10}$ from the Gulf of Alaska was negligible at this time. By $1500 \mathrm{LT}$, high concentrations of $\mathrm{PM}_{10}$ $\left(>24 \mu \mathrm{g} \cdot \mathrm{m}^{-3}\right)$ were visible east of Hugh Miller Inlet as a cruise-ship entered the park.

By 0100 LT the following morning, air from regions of high ship traffic outside Glacier Bay was orographically lifted over the Fairweather Mountain Range, leading to elevated $\mathrm{PM}_{10}$ concentrations even after the cruiseships had left the park. Wind speeds at 0100 LT approached upwards of about $15.4-20.6 \mathrm{~m} \cdot \mathrm{s}^{-1}$ (30 - $40 \mathrm{knots}$ ) over the Fairweather Mountain Range. This orographically forced lifting and subsequent adiabatic sinking advected pollutants into Glacier Bay. At this time, $\mathrm{PM}_{10}$ was still high in Glacier Bay from the cruise-ship entrances earlier in the day (e.g. southwest side of Glacier Bay). Although the steep mountainous terrain was smoothed in WRF/Chem, we have to assume that the advection of $\mathrm{PM}_{10}$ through geographically forced lifting of contaminated air is a potential threat for the pristine quality of air in Glacier Bay under such synoptic situations.

Despite the orographically forced lifting, pollutants remained close to the surface. The average $\mathrm{PM}_{10}$ concentration where ships travelled was roughly $16.8 \mu \mathrm{g} \cdot \mathrm{m}^{-3}$. At $1 \mathrm{~km}$ height, the $\mathrm{PM}_{10}$ concentrations returned to pristine conditions of $1.1 \mu \mathrm{g} \cdot \mathrm{m}^{-3}$.

\section{Conclusions}

Extensive periods of haze and visibility deterioration from atmospheric pollution attributed to cruise-ship emissions have been documented in the upper fjords of Glacier Bay since the 1970. However, since that time, cruise-ship technology has improved, and fuel content regulations and emission controls have been established [8]. Thus, despite cruise-ship size having increased, air-quality impacts have been reduced [29]. However, the increasing demand to visit Glacier Bay's tidal glaciers and pristine wilderness, as well as concerns regarding the formation of haze inside one of the largest wilderness areas in the U.S., requires management decisions and the setting of priorities. Thus, understanding the pollutant situation in Glacier Bay is an important prerequisite for successful actions in the future.

Simulations from the Weather Research and Forecasting Model, inline coupled with a chemistry package (WRF/Chem) were analyzed for the 124-day tourist season of 2008 to understand $\mathrm{PM}_{10}$ distributions and concentrations in Glacier Bay. The evaluation of the model results by data from 42 surface-based sites and one radiosonde showed that WRF/Chem captured the surface and upper air meteorological conditions with similar or better performance than other modeling studies performed in Alaska, or with WRF elsewhere. The mean biases for hourly air temperature, dew-point temperature, relative humidity, wind speed, wind direction, and pressure were $-0.6 \mathrm{~K},-0.2 \mathrm{~K}, 2 \%, 1.75 \mathrm{~m} \cdot \mathrm{s}^{-1}, 10^{\circ},-0.89 \mathrm{hPa}$, respectively. The error in the frequency of surface inversions was $9 \%$. Therefore, one can conclude that the WRF/Chem simulations are of sufficient accuracy to examine the fate of $\mathrm{PM}_{10}$ in response to cruise-ship emissions in Glacier Bay under various meteorological conditions.

The WRF/Chem simulations revealed notable trapping of $\mathrm{PM}_{10}$ sourced from cruise-ships while inversions were present inside Glacier Bay. Inversions typically developed in Glacier Bay during calm, clear weather patterns with low to no winds. Furthermore, they frequently formed due to radiative cooling, especially throughout the nighttime and early morning hours when the radiation balance was negative. According to the WRF/Chem simulations, inversions existed at least locally somewhere inside Glacier Bay on 52 out of the 124 days examined (42\%). The season-average inversion-strength and height was $1.19 \mathrm{~K}(100 \mathrm{~m})^{-1}$ and $92.5 \mathrm{~m}$, respectively. The strongest simulated inversion of $6.7 \mathrm{~K}(100 \mathrm{~m})^{-1}$ occurred on May 24 - 25 and lasted for 18 hours. Inversions typically lasted for 9 hours on average, with the longest being quasi-multi-day at roughly 60 hours. Con- 

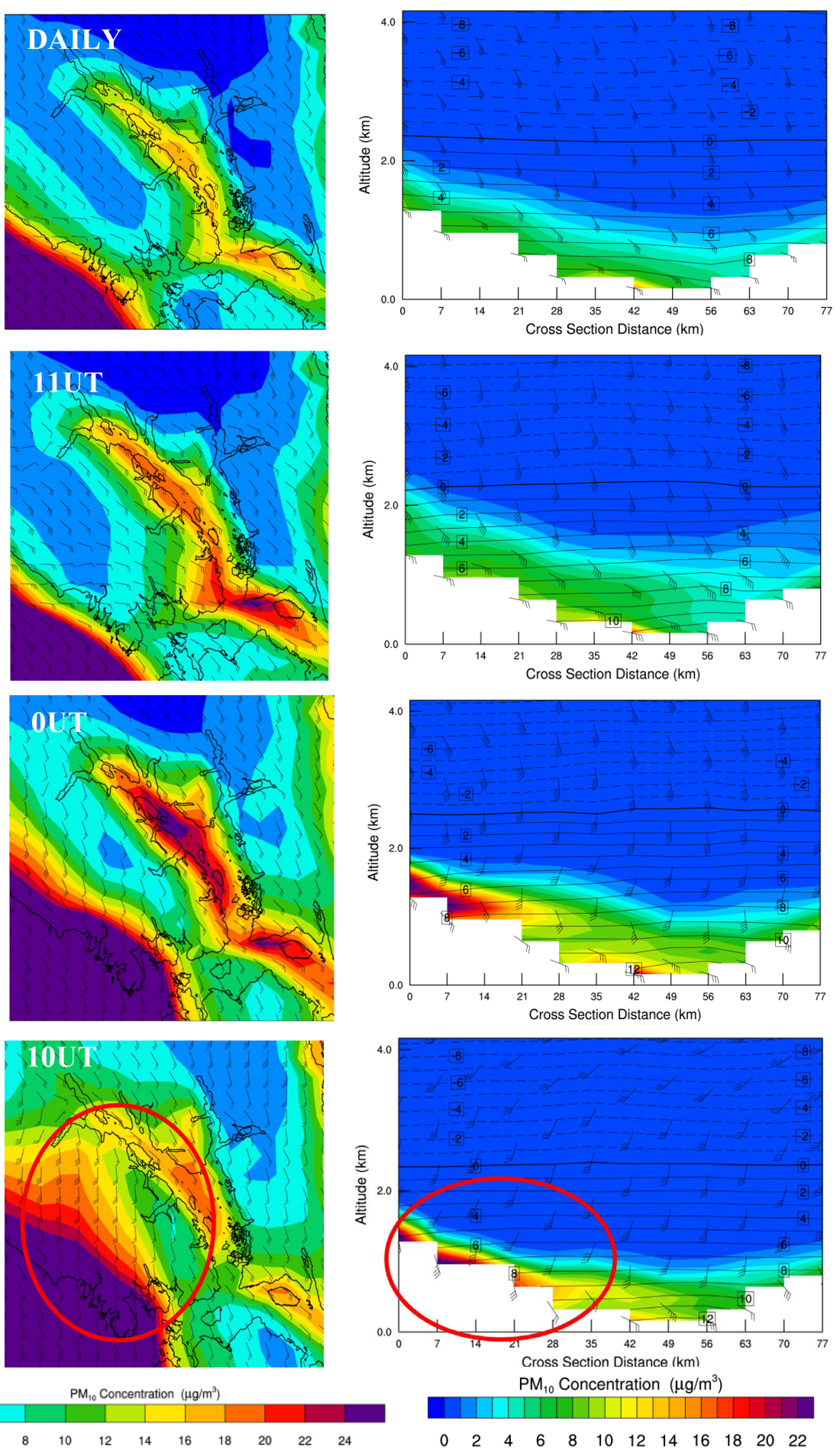

Figure 8. August 13-14 $\mathrm{PM}_{10}$ advection event in Glacier Bay. The left column shows zoomed-in contour plots depticitng $\mathrm{PM}_{10}$ concentrations during selected hours of the day. The right column illustrates the corresponding cross section plot taken from horizontal transects across central Glacier Bay. The top row shows the daily average contour and cross section plots. This event was the second highest day of pollution, strongly influenced by advection and orographic lifiting. At $11 \mathrm{UT}$, PM 10 was already being advected into Glacier Bay through Icy and Chatham Straits. Concentrations increased further by 0 UT when a cruise-ship was in the bay. Finally, the simulations show strong orographic lifting of $\mathrm{PM}_{10}$ over the Fairweather Mountain Range at $10 \mathrm{UT}$. High concentrations of $\mathrm{PM}_{10}$ appear to be forced over the mountains, indicated by the red ovals. All plots in each column have the same color scale. 
sequently, elevated $\mathrm{PM}_{10}$ concentrations from cruise-ship emissions were typically temporary until the polluted air was mixed out of Glacier Bay, thereby breaking the inversion and marginally augmenting the concentrations downwind. During the 124-day episode, one case involved the development of a mesoscale circulation inside Glacier Bay, trapping $\mathrm{PM}_{10}$ and dispersing the pollutants under the inversion level within the bay.

During the 2008 tourist season, hourly $\mathrm{PM}_{10}$ concentrations did not exceed $50 \mu \mathrm{g} \cdot \mathrm{m}^{-3}$ inside the park. This value is considerably below the 24-hour daily average National Ambient Air Quality Standards of $150 \mu \mathrm{g} \cdot \mathrm{m}^{-3}$ set by the U.S. EPA, which we use as a point of reference to weigh the severity of $\mathrm{PM}_{10}$ in relation to pollution levels in other parts of the United States. Daily 24-hour average $\mathrm{PM}_{10}$ concentrations were even lower (typically $<30 \mu \mathrm{g} \cdot \mathrm{m}^{-3}$ ).

This study shows that the $\mathrm{PM}_{10}$ situation in Glacier Bay is governed not only by the cruise-ship emissions inside the bay, but also by mesoscale features occurring inside the bay, as well as synoptic scale weather disturbances impacting Southeast Alaska at large. The WRF/Chem simulations showed that under certain synoptic conditions, pollutants from highly traveled areas near the park could become advected into portions of Glacier Bay. Such advection usually occurs under southwest winds. Then, air masses containing pollutants from ship traffic along the major sea lane can enter Icy Strait, and lead to elevated $\mathrm{PM}_{10}$ concentrations (compared to the pristine conditions above the ABL), especially into parts of lower Glacier Bay. Due to the model resolution, small fjords and inlets are subgrid-scale. Hence, the full magnitude of pollutant concentrations and the full impact of pollutant transport, and the persistence of inversions may be underestimated. A higher resolution simulation could shed some light on the currently unresolved mesoscale- $\gamma$ meteorological processes.

The WRF/Chem simulations also suggested that orographically forced lifting of pollutants over the Fairweather Mountain Range, as well as advection through Ice Strait might transport $\mathrm{PM}_{10}$ into Glacier Bay. These findings lead to the conclusion that $\mathrm{PM}_{10}$ concentrations and the pristine nature of Glacier Bay are not entirely controllable by restricting the number of cruise-ship entrances, and/or enforcing emission-control requirements inside Glacier Bay.

The multiple reasons for elevated $\mathrm{PM}_{10}$ concentrations in Glacier Bay, some of which are beyond the control of the National Park Service, lead to the conclusion that base-line in-situ weather and chemical observations should be established prior to any management changes in order to judge their effectiveness. While a network of monitoring stations may be costly and conflict with wilderness conditions, direct observations would provide much needed atmospheric information to better understand local effects that play significant roles on air quality inside the fjords of Glacier Bay, and may also aid in efficient management decisions. Such a network is also strongly needed to establish a baseline to measure the impact of management decisions or incidences.

\section{Acknowledgements}

We would like to thank Uma S. Bhatt, Igor Polyakov, and Joel Curtis for their helpful discussions, Jack R. Stickel for providing AK-DOT meteorological data, the Arctic Region Supercomputing Center of the Geophysical Institute at the University of Alaska Fairbanks for computational support, and the National Park Service for financial assistance (contract P11AT30883/P11AC90465). Hourly surface meteorological data are sourced from the National Climatic Data Center, National Data Buoy Center, and the Alaska Department of Transportation.

\section{References}

[1] NPS (2009) Foundation Statement. US Department of Interior. 43 p. http://www.nps.gov/glba/parkmgmt/upload/GLBA_Foundation.pdf

[2] Mölders, N., Gende, S. and Pirhalla, M. (2013) Assessment of Cruise-Ship Activity Influences on Emissions, Air Quality, and Visibility in Glacier Bay National Park. Atmospheric Pollution Research, 4, 435-445. http://dx.doi.org/10.5094/APR.2013.050

[3] Benson, C.S., Wendler, G. and March, R. (1978) On the Climate and Air Pollution Potential in Glacier Bay National Monument, Alaska. Report to the US National Park Service, Geophysical Institute, University of Alaska, Fairbanks, 33 p.

[4] Mölders, N. and Kramm, G. (2010) A Case Study on Wintertime Inversions in Interior Alaska with WRF. Atmospheric Research, 95, 314-332. http://dx.doi.org/10.5194/acp-13-9869-2013

[5] Shulski, M. and Wendler, G. (2007) The Climate of Alaska. University of Alaska Press, Fairbanks, 216 p. 
[6] Zhao, B.S., Wang, X., Liu, H., Xu, J.Y., Fu, K., Klimont, Z., Hao, J.M., He, K.B., Cofala, J. and Amann, M. (2013) $\mathrm{NO}_{\mathrm{x}}$ Emissions in China: Historical Trends and Future Perspectives. Atmosphere Chemistry Physics, 13, 9869-9897. http://dx.doi.org/10.5194/acp-13-9869-2013

[7] Bridgman, H.A., Schnell, R.C., Kahl, J.D., Herbert, G.A. and Joranger, E. (1989) A Major Haze Event near Point Barrow, Alaska: Analysis of Probable Source Regions and Transport Pathways. Atmospheric Environment, 23, 2537-2549. http://dx.doi.org/10.1016/0004-6981(89)90265-5

[8] Eyring, V., Köhler, H.W., van Aardenne, J. and Lauer, A. (2005) Emissions from International Shipping: 1. The Last 50 Years. Journal of Geophysical Research: Atmospheres, 110, Published Online.

[9] Skamarock, W.C., Klemp, J.B., Dudhia, J., Gill, D.O., Barker, D.M., Duda, M.G., Huang, X., Wang, W. and Powers, J.G. (2008) A Description of the Advanced Research WRF Version 3. NCAR Technical Note, NCAR/TN-475+STR, $125 \mathrm{p}$.

[10] Grell, G.A., Peckham, S.E., Schmitz, R., McKeen, S.A., Frost, G., Skamarock, W.C. and Eder, B. (2005) Fully Coupled "Online" Chemistry within the WRF Model. Atmospheric Environment, 39, 6957-6975. http://dx.doi.org/10.1016/j.atmosenv.2005.04.027

[11] Peckham, S.E., Grell, G.A., McKeen, S.A., Barth, M., Pfister, G., Wiedinmyer, C., Fast, J.D., Gustafson, W.I., Ghan, SJ., Easter, R.C., Barnard, J. and Chapman, E. (2011) WRF/Chem Version 3.3 User's Guide. 94 p.

[12] Hong, S.Y. and Lim, J.O.J. (2006) The WRF Single-Moment 6-Class Microphysics Scheme (WSM6). Journal of the Korean Meteorological Society, 42, 129-151.

[13] Grell, G.A. and Dévényi, D. (2002) A Generalized Approach to Parameterizing Convection Combining Ensemble and Data Assimilation Techniques. Geophysical Research Letters, 29, 38-34.

[14] Barnard, J., Fast, J., Paredes-Miranda, G., Arnott, W. and Laskin, A. (2010) Technical Note: Evaluation of the WRFChem “Aerosol Chemical to Aerosol Optical Properties” Module Using Data from the MILAGRO Campaign. Atmospheric Chemistry and Physics, 10, 7325-7340. http://dx.doi.org/10.5194/acp-10-7325-2010

[15] Chou, M.D. and Suarez, M.J. (1994) An Efficient Thermal Infrared Radiation Parameterization for Use in General Circulations Models. NASA Tech. Memo. 104606, Vol. 10, 85 p.

[16] Mlawer, E.J., Taubman, S.J., Brown, P.D., Iacono, M.J. and Clough, S.A. (1997) Radiative Transfer for Inhomogeneous Atmospheres: RRTM, a Validated Correlated-K Model for the Longwave. Journal of Geophysical Research: Atmospheres, 102, 16663-16682. http://dx.doi.org/10.1029/97JD00237

[17] Mellor, G.L. and Yamada, T. (1982) Development of a Turbulence Closure Model for Geophysical Fluid Problems. Review of Geophysics. Space Physics, 20, 851-875. http://dx.doi.org/10.1029/RG020i004p00851

[18] Janjić, Z.I. (2002) Nonsingular Implementation of the Mellor-Yamada Level 2.5 Scheme in the NCEP Meso Model. NCEP Office Note No. 437, 61 p.

[19] Chen, F. and Dudhia, J. (2001) Coupling an Advanced Land Surface Hydrology Model with the Penn State/NCAR MM5 Modeling System. Part I: Model Implementation and Sensitivity. Monthly Weather Review, 129, 569-585. http://dx.doi.org/10.1175/1520-0493(2001)129<0569:CAALSH>2.0.CO;2

[20] Stockwell, W.R., Middleton, P., Chang, J.S. and Tang, X. (1990) The Second Generation Regional Acid Deposition Model Chemical Mechanism for Regional Air Quality Modeling. Journal of Geophysical Research: Atmospheres, 95, 16343-16367. http://dx.doi.org/10.1029/JD095iD10p16343

[21] Middleton, P., Stockwell, W.R. and Carter, W.P.L. (1990) Aggregation and Analysis of Volatile Organic Compound Emissions for Regional Modeling. Atmospheric Environment, Part A, General Topics, 24, 1107-1133. http://dx.doi.org/10.1016/0960-1686(90)90077-Z

[22] Madronich, S. (1987) Photodissociation in the Atmosphere, 1, Actinic Flux and the Effects of Ground Reflections and Clouds. Journal of Geophysical Research: Atmospheres, 92, 9740-9752. http://dx.doi.org/10.1016/S1352-2310(98)00006-5

[23] Ackermann, I.J., Hass, H., Memmesheimer, M., Ebel, A., Binkowski, F.S. and Shankar, U. (1998) Modal Aerosol Dynamics Model for Europe: Development and First Applications. Atmospheric Environment, 32, 2981-2999. http://dx.doi.org/10.1016/S1352-2310(98)00006-5

[24] Schell, B., Ackermann, I.J., Hass, H., Binkowski, F.S. and Ebel, A. (2001) Modeling the Formation of Secondary Organic Aerosol within a Comprehensive Air Quality Model System. Journal of Geophysical Research: Atmospheres, 106, 28275-28293. http://dx.doi.org/10.1029/2001JD000384

[25] Wesely, M.L. (1989) Parameterization of Surface Resistance to Gaseous Dry Deposition in Regional Numerical Models. Atmospheric Environment, 16, 1293-1304. http://dx.doi.org/10.1016/0004-6981(89)90153-4

[26] Mölders, N., Tran, H.N.Q., Quinn, P., Sassen, K., Shaw, G.E. and Kramm, G. (2011) Assessment of WRF/Chem to Simulate Sub-Arctic Boundary Layer Characteristics during Low Solar Irradiation Using Radiosonde, SODAR, and 
Surface Data. Atmospheric Pollution Research, 2, 283-299. http://dx.doi.org/10.5094/APR.2011.035

[27] Guenther, A., Zimmerman, P. and Wildermuth, M. (1994) Natural Volatile Organic Compound Emission Rate Estimates for U.S. Woodland Landscapes. Atmospheric Environment, 28, 1197-1210. http://dx.doi.org/10.1016/1352-2310(94)90297-6

[28] Simpson, D., Guenther, A., Hewitt, C.N. and Steinbrecher, R. (1995) Biogenic Emissions in Europe: 1. Estimates and Uncertainties. Journal of Geophysical Research: Atmospheres, 100, 22875-22890. http://dx.doi.org/10.1029/95JD02368

[29] Pirhalla, M.A. (2014) Assessment of Particulate Accumulation Climatology under Inversions in Glacier Bay for the 2008 Tourist Season Using WRF/Chem Data. M.S. Thesis, Department of Atmospheric Sciences, University of Alaska, Fairbanks, 148 p.

[30] Hines, K.M. and Bromwich, D.H. (2008) Development and Testing of Polar Weather Research and Forecasting (WRF) Model. Part I: Greenland Ice Sheet Meteorology. Monthly Weather Review, 136, 1971-1989. http://dx.doi.org/10.1175/2007MWR2112.1

[31] Cassano, J.J., Higgins, M.E. and Seefeldt, M.W. (2011) Performance of the Weather Research and Forecasting Model for Month-Long Pan-Arctic Simulations. Monthly Weather Review, 139, 3469-3488. http://dx.doi.org/10.1175/MWR-D-10-05065.1

[32] Mölders, N. (2008) Suitability of the Weather Research and Forecasting (WRF) Model to Predict the June 2005 Fire Weather for Interior Alaska. Weather and Forecasting, 23, 953-973. http://dx.doi.org/10.1175/2008WAF2007062.1

[33] PaiMazumder, D. and Mölders, N. (2009) Theoretical Assessment of Uncertainty in Regional Averages Due to Network Density and Design. Journal of Applied Meteorology and Climatology, 48, 1643-1666. http://dx.doi.org/10.1175/2009JAMC2022.1

[34] McGrath, R., Semmler, T., Sweeney, C. and Wang, S. (2006) Impact of Balloon Drift Errors in Radiosonde Data on Climate Statistics. Journal of Climate, 19, 3430-3442. http://dx.doi.org/10.1175/JCLI3804.1

[35] EPA (2012) Our Nation's Air: Status and Trends through 2010. US EPA Office of Air Quality Planning and Standards, Research Triangle Park, 27 p. 
Scientific Research Publishing (SCIRP) is one of the largest Open Access journal publishers. It is currently publishing more than 200 open access, online, peer-reviewed journals covering a wide range of academic disciplines. SCIRP serves the worldwide academic communities and contributes to the progress and application of science with its publication.

Other selected journals from SCIRP are listed as below. Submit your manuscript to us via either submit@scirp.org or Online Submission Portal.
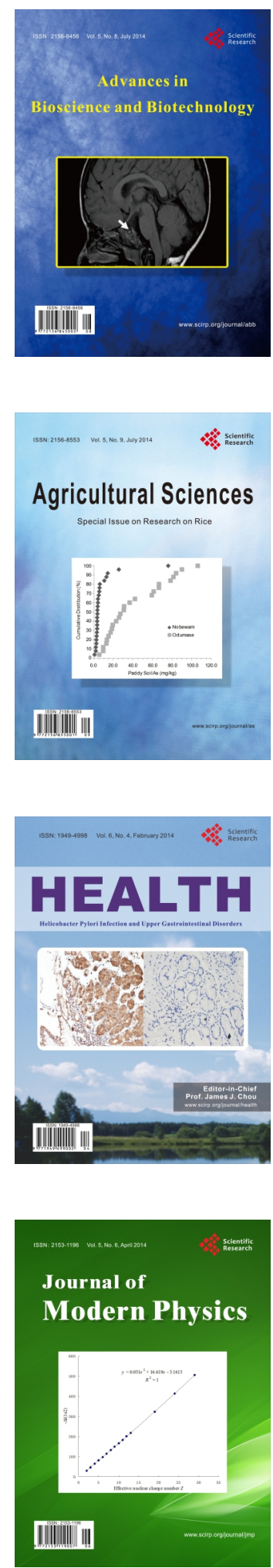
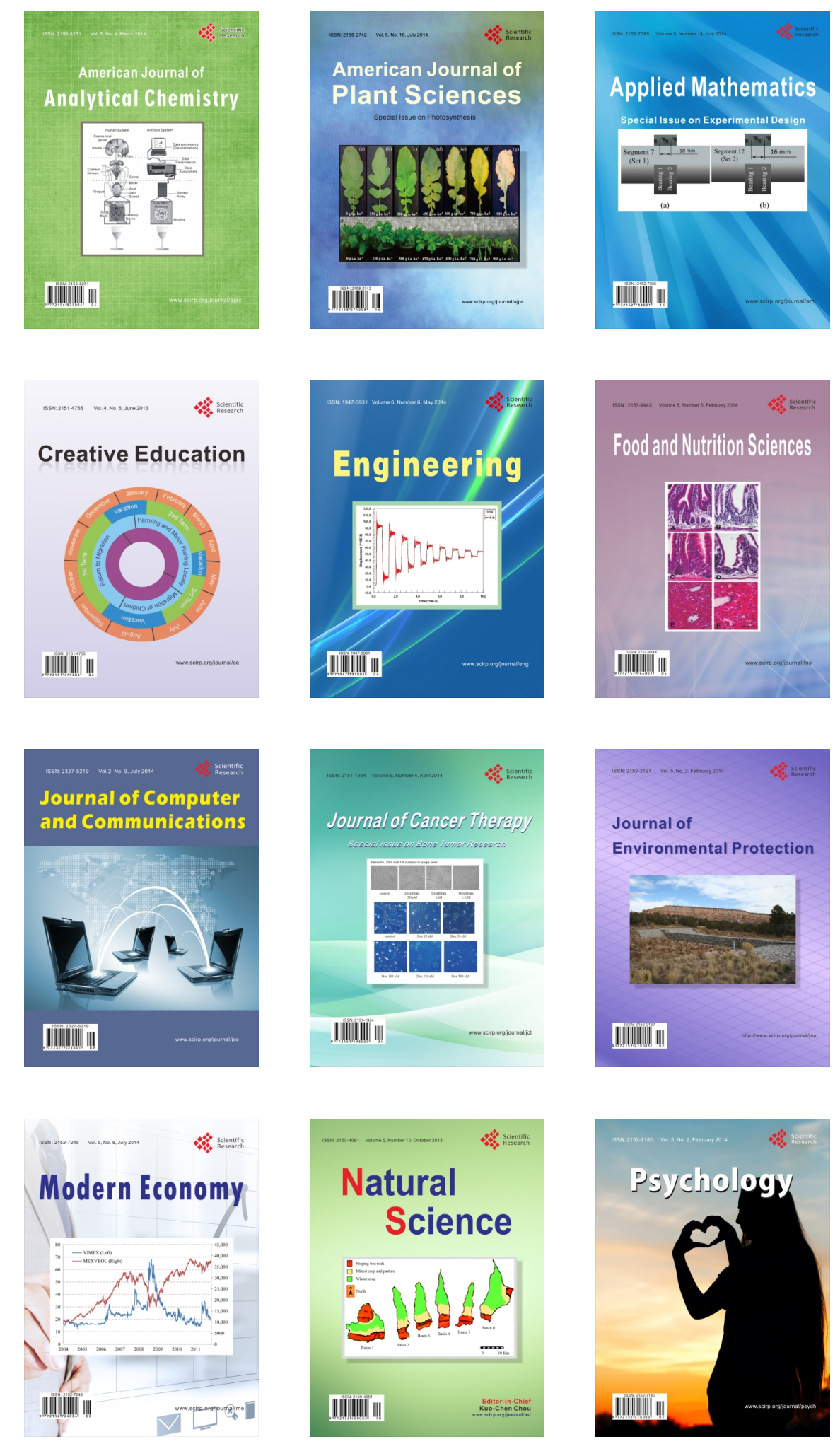